\title{
Promoting EF With Preschool Interventions: Lessons Learned From 15 Years of Conducting Large-Scale Studies
}

\author{
Shira Mattera ${ }^{1 *}$, Natalia M. Rojas ${ }^{2}$, Pamela A. Morris ${ }^{3}$ and Karen Bierman ${ }^{4}$ \\ ${ }^{1}$ MDRC, New York, NY, United States, ${ }^{2}$ Department of Population Health, New York University School of Medicine, New \\ York, NY, United States, ${ }^{3}$ Department of Applied Psychology, New York University, New York, NY, United States, \\ ${ }^{4}$ Department of Psychology, Pennsylvania State University, State College, PA, United States
}

OPEN ACCESS

Edited by:

Antje Von Suchodoletz,

New York University Abu Dhabi,

United Arab Emirates

Reviewed by:

Regula Neuenschwander, University of Bern, Switzerland

Laura Traverso,

University of Genoa, Italy

*Correspondence:

Shira Mattera

shira.mattera@mdrc.org

Specialty section: This article was submitted to

Developmental Psychology, a section of the journa

Frontiers in Psychology

Received: 11 December 2020 Accepted: 22 April 2021

Published: 24 June 2021

Citation:

Mattera S, Rojas NM, Morris PA and Bierman K (2021) Promoting EF With

Preschool Interventions: Lessons Learned From 15 Years of Conducting

Large-Scale Studies.

Front. Psychol. 12:640702.

doi: 10.3389/fpsyg.2021.640702
In the past two decades, a growing number of early childhood interventions that aim to improve school readiness have also targeted children's executive function (EF), building on the theory that promoting EF skills in preschool may play a key role in reducing the substantial gaps in school readiness and later achievement associated with family income. Despite the expansion of school readiness interventions across preschool, research evidence is mixed regarding what works to promote EF development and the impact of these interventions on children's EF skills, and subsequently, their academic and behavioral outcomes. This paper reviews four intervention approaches designed to support school readiness that may also improve children's EF skills by: (a) encouraging adaptive classroom behaviors, (b) improving social-emotional learning, (c) promoting play and direct training of EF skills, and (d) improving cognitive skills related to EF. We describe program effects from rigorous trials testing these approaches, including summarizing the takeaways from four large-scale intervention research studies conducted by the authors, involving over 5,000 children. We conclude by exploring open questions for the field and future directions for research and intervention program development and refinement.

Keywords: executive function, preschool, interventions, school readiness, academic achievement

\section{INTRODUCTION}

Children's executive function (EF) has been seen as a potentially potent target of early childhood interventions over the past 15 to 20 years. EF reflect a child's capacity to exert self-regulatory cognitive processes in order to achieve a goal (Garon et al., 2008). These overarching functions help a child manage their cognitive, social, emotional, and behavioral responses, especially in situations requiring novel problem-solving. EFs are used for difficult tasks that evoke effortful selfmonitoring, instead of automated responses (Hughes and Graham, 2002). Whereas crystallized cognition encompasses basic knowledge and facts, EF represents while fluid cognition and reflects cognitive-based processes that oversee, or execute, the use of behavioral and cognitive strategies (Blair, 2006).

Children living in poverty often experience environments that can hamper the development of EF skills (Noble et al., 2007), which lay the groundwork for the development of mental systems that support self-regulation and adaptive learning behaviors (Blair, 2002). EF has been identified as a promising lever for the preschool years because those skills: (1) normatively undergo significant 
growth during the preschool years, (2) are considered malleable, and (3) are associated with improved social-emotional and academic outcomes. The hope was that if existing schoolreadiness-focused preschool interventions could also increase the speed of growth of EF skills, they may initiate a cascade of positive subsequent social, behavioral, and academic benefits.

The focus on EF as a target of intervention in the preschool years emerged from two parallel sets of research in the early 2000s. Neuro-developmental work at the time was extending the study of EF in adults down to the earlier years, spurring work that examined the development and importance of EF in young children. A growing body of literature at the time pointed to evidence that EF skills grow and change in a dramatic fashion during the preschool years (e.g., Hughes, 1998; Carlson, 2005; Garon et al., 2008). Correlational research on children's preschool skills suggested that EF underlay a child's ability to self-regulate which, in turn, was associated with more adaptive approaches to learning in the classroom, improved school readiness, and stronger academic skills documented through the sixth grade (e.g., Blair, 2002; Raver, 2002; Espy et al., 2004; McClelland et al., 2006).

At the same time, federal funding priorities in the United States supported a burst in translational research aimed to test preschool programs that could improve school readiness, many with an emphasis on promoting self-regulation as a key outcome (e.g., Webster-Stratton, 1994; Lynch et al., 2004; Domitrovich et al., 2007). Self-regulation has been conceptualized as a larger umbrella term that, in addition to EF, includes regulation of children's behavior, cognition, and emotion (e.g., Raver, 2002). Interestingly, the early childhood programs that also aimed to promote children's self-regulation varied in their conceptual foundations and approaches to improving self regulation. Some of these programs trained teachers in behavior management strategies to encourage adaptive classroom behaviors (e.g., Incredible Years, WebsterStratton et al., 2001). Others used a curriculum as a vehicle for directly improving social-emotional learning (e.g., Preschool PATHS, Lynch et al., 2004; Domitrovich et al., 2007). Another approach promoted play and direct training of EF skills (e.g., Tools of the Mind, Bodrova and Leong, 2006; Red Light, Purple Light; McClelland et al., 2007). A final approach improved cognitive skills related to EF (e.g., Building Blocks, Clements and Sarama, 2008).

These two sets of research came together to inform a subsequent set of randomized trials of school readiness programs that included explicit measures of EF as well as behavioral measures of self-regulation, with potential to shed light on the effects of these programs on EF and related behavioral and emotional skills and behaviors (e.g., Head Start REDI, Chicago School Readiness Project, Foundations of Learning, Head Start CARES, Making Pre-K Count). Mixed findings emerged from these studies; it was not clear whether curricula that targeted school readiness domains such as cognition (reading, math), social-emotional development, and self-regulation skills significantly improved children's EF skills, and subsequently, children's academic skills. Experts suggested several reasons why there may not have been consistent observable impacts of school readiness interventions on children's EF outcomes, including definitional and measurement issues or curricula that are too complex or hard to implement (Jacob and Parkinson, 2015). While a number of meta-analyses have examined the effects of programs designed specifically to directly improve EF (e.g., Takacs and Kassai, 2019; Pauli-Pott et al., 2020; Scionti et al., 2020), few discussions have synthesized and delved into the effects specifically of these school-readiness-focused programs.

Building from our 15 years of experience conducting schoolbased RCTs, in this paper we describe different approaches school readiness-focused programs have taken to improve EF in early childhood, lay out the evidence base around those approaches including findings from large-scale preschool intervention studies that also targeted EF as an outcome of interest, and explore future directions for research and intervention program development and refinement.

\section{Large-Scale Studies of Preschool Interventions Targeting EF}

Four large-scale, rigorous studies of five school readiness-focused preschool programs provide a foundation for the authors' reflections on EF. These cluster-randomized controlled trials span 23 cities and 268 preschool sites or centers and include over 5,000 4-year-old children (see Tables 1-4 for more detail about each study):

Foundations of Learning (FOL) combined teacher training in effective classroom management (Incredible Years Teacher Training Program, Webster-Stratton et al., 2004) with weekly classroom consultation (Morris et al., 2013). FOL rigorously tested this model by randomly assigning 71 centers to the program or a preschool-as-usual control condition in two sites (Chicago and Newark, NJ). One thousand two hundred three 4-year old children were assessed at the end of preschool. The study built upon an earlier smaller efficacy trial of the same multicomponent model (Chicago School Readiness Project; Raver et al., 2008, 2009).

Head Start CARES was a national, large-scale demonstration project explicitly designed to test three distinct approaches to enhancing children's social-emotional development in Head Start classrooms (Mattera et al., 2013; Morris et al., 2014). The three programs contrast alternative "levers for change" operating at different levels of the child's ecology. The study was a rigorous cluster-randomized controlled trial with over 100 preschools and 300 classrooms; 2,114 4-year-old children were assessed at the end of preschool. The three models tested were: The Incredible Years Teacher Training Program (IY), Preschool PATHS (Promoting Alternative Thinking Strategies; PATHS), and Tools of the Mind-Play (Tools-Play).

Head Start REDI (Research-based, Developmentally Informed) enriched Head Start classrooms with a socialemotional learning program (the Preschool PATHS Curriculum) and an interactive reading program, using daily small group reading sessions to reinforce PATHS social-emotional themes (Bierman et al., 2008). Weekly "sound games" and print center activities were also included, with the overall goal of promoting children's school readiness in areas of social-emotional learning, 
TABLE 1 | Background characteristics of the behavioral-focused studies.

\section{Study characteristics The Incredible Years}

Webster-Stratton et al. (2004)

Raver et al., 2009, 201

Foundations of

Morris et al., 2013

Paired randomized trial, Head

Families were assigned at

random to one of six conditions:

$+\Pi$ ); child training plus teacher child training combined with

Study location

Sample size clinicians

Child sample

demographics

90\% boys, $79 \%$ Euro-American,

\section{Intervention characteristics}

Duration of

implementation

Amount of training and Teachers: 4 days of training

coaching

\section{Measures}

Teacher practice

Classroom climate

impressions inventory (OA)

Executive function and Teacher assessment of schoo behavioral regulation behavior (TR); MOOSES (OA); social health profile (AR)

Emotion knowledge

and socia

Perceived competence scale for

problem-solving skills

Learning and social

behaviors

Academic outcomes parent training alone (PT); child training alone (CT); parent

training plus teacher training (PT training $(C T+\Pi)$; parent and teacher training $(P T+C T+T T$ ) and a waiting list control group Washington state

159 children and families; 8 with a mean age of 70.99 months

1 year

Classroom atmosphere measure (OA) young children (TR) assigned to the intervention or business as usual control condition

\section{Chicago, II}

18 sites; 90 Head Start

classrooms; 87 teachers; 543 children

67\% African-American, 25\% Hispanic, and $3 \%$ white, with a mean age of 49.4 months

1 year

5 training sessions ( $30 \mathrm{~h}$ total); weekly coaching visits

\section{CLASS (OA); ECERS-R (OA)}

Behavioral problem index (TR) caregiver-teacher report form (TR); penn interactive peer play scale (OA); PSRA (AR); balance beam (DA); pencil tap (DA)

Toy wrap (DA); toy wait (DA); snack delay (DA); tongue task (DA)

DPIS (DA)

PreLAS (DA); peabody picture vocabulary test (DA); early math skills (DA)
Randomized trial, Head Start centers were randomly assigned to the FOL intervention or business as usual control condition

\section{Newark, NJ}

51 sites; 51

classrooms/teachers; 531

children

68\% African-American, 28\%

Hispanic, and 2\% White, with a

mean age of 4.1 years

1 year

5 training sessions; weekly coaching visits

CLASS (OA)

Behavioral problem index (TR): caregiver-teacher report form (TR); cooper-farran behaviora ratings scale (TR)

Student-Teacher relationships scale (TR)

inCLASS (OA); positive behavio scale (TR)

Academic rating scale (TR)
Foundations of Learning-Chicago Morris et al., 2013

Randomized trial; Head Start, schools were randomly assigned to the FOL intervention or business a usual control condition

Thcredible Years-CARES study Mattera et al., 2013; Morris et al.,

luster randomized trial; centers randomly assigned to one of three curricula (IY, PP, or TM) or business-as usual control condition

\section{Chicago, I}

20 sites; 40 classrooms/teachers: 307 children

43\% African-American, 35\% Hispanic, and 10\% White, with mean age 4.4 years

1 year

5 training sessions; weekly coaching visits

inCLASS (OA); Behavioral problem index (TR); caregiver-teacher report form (TR); cooper-farran behavioral ratings scale (TR); head-to-toes (DA) pencil tap (DA); gift wrap (TR): preschool self-regulation interviewer assessment (AR)

Challenging situations (DA)

Positive behavior scale (TR)

WJ-III Letter-word identification (DA): WJ-III applied problems (DA): peabody picture vocabulary test (DA): academic rating scale (TR)
17 Head Start grantees located in 10 states across the United States

104 sites; 307 classrooms; 2,114 (total sample) and 702 incredible years program group children $43 \%$ were Hispanic, $33 \%$ African-American, and 16\% white, with a mean age 4.4 years

1 year

6 training sessions; weekly coaching visits

Adapted teacher style rating scale (TSRS) (OA)

CLASS (OA)

Head-to-Toes (DA); pencil tap (DA); behavioral problem index (TR)

Facial emotions identification tasks (DA); emotion situation tasks (DA) challenging situations task (DA) Social skills rating system (TR)

WJ-III Letter-word identification (DA) WJ-III applied problems (DA):

EOWPVT (DA); academic rating scale (TR)

$D A$, direct child assessment; TR, teacher-report; OA, observational assessment; AR, assessor-report. 
TABLE 2 | Background characteristics of the social-emotional learning studies.

\begin{tabular}{|c|c|c|c|}
\hline Study characteristics & $\begin{array}{l}\text { Preschool PATHS } \\
\text { Domitrovich et al., } 2007\end{array}$ & $\begin{array}{l}\text { Preschool PATHS-CARES study } \\
\text { Mattera et al., 2013; Morris et al., } 2014\end{array}$ & $\begin{array}{l}\text { Head Start REDI } \\
\text { Bierman et al., 2008; Domitrovich et al., } 2009\end{array}$ \\
\hline Design overview & $\begin{array}{l}\text { Mixed-block randomized trial; classrooms were } \\
\text { randomly assigned to either preschool PATHS or } \\
\text { business-as-usual control condition }\end{array}$ & $\begin{array}{l}\text { Cluster randomized trial; centers randomly assigned } \\
\text { to one of three curricula (IY, PP, or TM) or } \\
\text { business-as usual control condition }\end{array}$ & $\begin{array}{l}\text { Cluster randomized trial; centers randomly assigned } \\
\text { to intervention or business-as-usual condition }\end{array}$ \\
\hline Sample location & Central Pennsylvania & $\begin{array}{l}17 \text { head start grantees located in } 10 \text { states across } \\
\text { the United States }\end{array}$ & Pennsylvania \\
\hline Sample size & $\begin{array}{l}2 \text { head start programs; } 20 \text { classrooms/teachers; } \\
246 \text { children }\end{array}$ & $\begin{array}{l}307 \text { classrooms; } 2,114 \text { (total sample) and } 669 \\
\text { preschool Paths program group children }\end{array}$ & 44 head start classrooms/teachers; 356 children \\
\hline Child sample demographics & $\begin{array}{l}47 \% \text { African-American, } 38 \% \text { European-American, } \\
\text { and } 20 \% \text { were Hispanic with a mean age of } 51.40 \\
\text { months. }\end{array}$ & $\begin{array}{l}43 \% \text { were Hispanic, } 33 \% \text { African-American, and } \\
16 \% \text { White, with a mean age } 4.49 \text { years }\end{array}$ & 356 children: 17\% Hispanic, $25 \%$ African-American \\
\hline \multicolumn{4}{|l|}{ Intervention characteristics } \\
\hline Duration of implementation & 1 year & 1 year & 1 year \\
\hline Amount of training and coaching & 3 days; monthly coaching visits & 4 training sessions; weekly coaching visits & Training sessions and weekly coaching visits \\
\hline \multicolumn{4}{|l|}{ Measures } \\
\hline Teacher practice & & Adapted teacher style rating scale (TSRS) (OA) & \\
\hline Classroom climate & & CLASS (OA) & \\
\hline $\begin{array}{l}\text { Executive function and } \\
\text { behavioral regulation }\end{array}$ & $\begin{array}{l}\text { Day/Night task (DA); Attention sustained subtest } \\
\text { from the leiter-revised assessment battery (DA); } \\
\text { Problem behavior scale of the PKBS (TR) }\end{array}$ & $\begin{array}{l}\text { Head-to-Toes (DA); pencil Tap (DA); behavioral } \\
\text { problem index (TR) }\end{array}$ & ADHD rating scale (TR) \\
\hline $\begin{array}{l}\text { Emotion knowledge and social } \\
\text { problem-solving skills }\end{array}$ & $\begin{array}{l}\text { Recognition of emotions concepts from KEI (DA); } \\
\text { assessment of children's emotions scale (DA); } \\
\text { Denham puppet interview (DA); challenging } \\
\text { situations (DA) }\end{array}$ & $\begin{array}{l}\text { Facial emotions identification tasks (DA); emotion } \\
\text { situation tasks (DA); challenging situations task (DA) }\end{array}$ & $\begin{array}{l}\text { Children's emotion skills (DA); emotion recognition } \\
\text { questionnaire (DA); challenging situations tasks (DA) }\end{array}$ \\
\hline Learning and social behaviors & Social skills scale of the PKBS (TR) & Social skills rating system (TR) & $\begin{array}{l}\text { Social competence scale (TR); Teacher observation } \\
\text { of child adaptation-revised (TR); learning } \\
\text { engagement (TR) }\end{array}$ \\
\hline Academic outcomes & & $\begin{array}{l}\text { WJ-III Letter-word identification (DA); WJ-III applied } \\
\text { problems (DA); EOWPVT (DA); academic rating } \\
\text { scale (TR) }\end{array}$ & $\begin{array}{l}\text { EOWPVT (DA); Grammatical understanding subtest } \\
\text { of the test of language development (DA); Test of } \\
\text { preschool early literacy (DA) }\end{array}$ \\
\hline
\end{tabular}

$D A$, direct child assessment; TR, teacher-report; $O A$, observational assessment; $A R$, assessor-report. 
TABLE 3 | Background characteristics of the promoting play and direct training studies.

\begin{tabular}{|c|c|c|c|c|c|c|c|}
\hline $\begin{array}{l}\text { Study } \\
\text { characteristics }\end{array}$ & $\begin{array}{l}\text { Tools of the Mind } \\
\text { Diamond et al., } 2007\end{array}$ & $\begin{array}{l}\text { Tools of the Mind } \\
\text { Clements et al., } 2020\end{array}$ & $\begin{array}{l}\text { Tools of the Mind } \\
\text { Lonigan and Phillips, } \\
2012\end{array}$ & $\begin{array}{l}\text { Tools of the Mind } \\
\text { Farran and Wilson, } \\
2014\end{array}$ & $\begin{array}{l}\text { Tools of the } \\
\text { Mind-Play-CARES } \\
\text { study } \\
\text { Mattera et al., 2013; } \\
\text { Morris et al., } 2014\end{array}$ & $\begin{array}{l}\text { Tools of the Mind } \\
\text { Solomon et al., } 2018\end{array}$ & $\begin{array}{l}\text { Red Light/Purple } \\
\text { Light } \\
\text { McClelland et al., } \\
2019\end{array}$ \\
\hline Design overview & $\begin{array}{l}\text { Children were randomly } \\
\text { assigned to classrooms } \\
\text { with tools of the mind } \\
\text { or literacy in a balanced } \\
\text { way curriculum }\end{array}$ & $\begin{array}{l}\text { Three-armed cluster } \\
\text { randomized control } \\
\text { trial; classrooms } \\
\text { randomly assigned to } \\
\text { three conditions } \\
\text { (building blocks; } \\
\text { building blocks and } \\
\text { scaffolding } \\
\text { self-regulation; and } \\
\text { business-as-usual } \\
\text { control condition) }\end{array}$ & $\begin{array}{l}\text { Cluster randomized } \\
\text { trial; centers } \\
\text { randomized to one of } \\
\text { four conditions (tools of } \\
\text { the mind, literacy } \\
\text { express comprehensive } \\
\text { preschool curriculum; } \\
\text { combined curriculum; } \\
\text { or business-as-usual } \\
\text { condition) }\end{array}$ & $\begin{array}{l}\text { Cluster randomized } \\
\text { trial; centers } \\
\text { randomized to tools of } \\
\text { the mind condition or } \\
\text { business-as-usual } \\
\text { condition }\end{array}$ & $\begin{array}{l}\text { Cluster randomized } \\
\text { trial; centers randomly } \\
\text { assigned to one of } \\
\text { three curricula (IY, PP, } \\
\text { or TM) or business-as } \\
\text { usual control condition }\end{array}$ & $\begin{array}{l}\text { Cluster-randomized } \\
\text { trial; centers randomly } \\
\text { assigned to tools of the } \\
\text { mind condition or } \\
\text { YMCA playing to learn } \\
\text { curriculum condition }\end{array}$ & $\begin{array}{l}\text { Block randomized trial; } \\
\text { teachers were } \\
\text { randomized into one of } \\
\text { the three conditions } \\
\text { (the self-regulation only } \\
\text { version, the } \\
\text { self-regulation plus } \\
\text { math and reading } \\
\text { version, or } \\
\text { business-as-usual) }\end{array}$ \\
\hline Sample location & $\begin{array}{l}\text { Northeast of the } \\
\text { United States }\end{array}$ & San Diego county & $\begin{array}{l}\text { New Mexico and } \\
\text { Massachusetts }\end{array}$ & 2 southern states & $\begin{array}{l}17 \text { Head Start grantees } \\
\text { located in } 10 \text { states } \\
\text { across the } \\
\text { United States }\end{array}$ & Ontario, Canada & $\begin{array}{l}\text { Pacific North West of } \\
\text { the United States }\end{array}$ \\
\hline Sample size & 147 children & $\begin{array}{l}84 \\
\text { classrooms/teachers; } \\
837 \text { children }\end{array}$ & $\begin{array}{l}117 \\
\text { classrooms/teachers; } \\
2,564 \text { children }\end{array}$ & $\begin{array}{l}60 \\
\text { classrooms/teachers; } \\
877 \text { children }\end{array}$ & $\begin{array}{l}307 \text { classrooms; } 2,114 \\
\text { (total sample) and } 678 \\
\text { tools-Play program } \\
\text { group child sample }\end{array}$ & $\begin{array}{l}20 \\
\text { classrooms/teachers; } \\
256 \text { children }\end{array}$ & $\begin{array}{l}13 \\
\text { classrooms/teachers; } \\
188 \text { children }\end{array}$ \\
\hline $\begin{array}{l}\text { Child sample } \\
\text { demographics }\end{array}$ & $\begin{array}{l}91 \% \text { Hispanic with } \\
\text { mean age of } 5.1 \text { years }\end{array}$ & $\begin{array}{l}39 \% \text { Hispanic, Asian } \\
\text { Pacific Islander } 18 \% \text {, } \\
\text { African-American } 11 \% \text {, } \\
\text { and } 31 \% \text { non-Hispanic } \\
\text { White }\end{array}$ & $\begin{array}{l}52 \% \text { Latino, } 38 \% \\
\text { non-Latino with a mean } \\
\text { age of } 52.7 \text { months }\end{array}$ & $\begin{array}{l}\text { 39\% White; 29\% } \\
\text { Black; 24\% Hispanic; } \\
6 \% \text { Asian, mean age } \\
54.1 \text { months (Tools } \\
\text { sample); } 41 \% \text { White; } \\
23 \% \text { Black; } 25 \% \\
\text { Hispanic; } 6 \% \text { Asian, } \\
\text { mean age } 54.6 \text { months } \\
\text { (Non-Tools sample) }\end{array}$ & $\begin{array}{l}43 \% \text { were Hispanic, } \\
33 \% \text { African-American, } \\
\text { and } 16 \% \text { White, with a } \\
\text { mean age } 4.49 \text { years } \\
\text { (full sample) }\end{array}$ & $\begin{array}{l}\text { Study did not report } \\
\text { the demographic } \\
\text { information for children; } \\
\text { mean age } 45.9 \text { months }\end{array}$ & $\begin{array}{l}58 \% \text { Latino, } 26 \% \\
\text { White, } 7 \% \text { Pacific } \\
\text { Islander, } 6 \% \text { African } \\
\text { American with a mean } \\
\text { age of } 51 \text { months }\end{array}$ \\
\hline \multicolumn{8}{|c|}{ Intervention characteristics } \\
\hline $\begin{array}{l}\text { Duration of } \\
\text { implementation }\end{array}$ & 2 years & 2 years & 2 years & 2 years & 1 year & 2 years & 8 weeks \\
\hline $\begin{array}{l}\text { Amount of training } \\
\text { and coaching }\end{array}$ & $\begin{array}{l}7 \text { days of training in } \\
\text { year one; } 2.5 \text { days of } \\
\text { training in year } 2 \text {; } \\
\text { coaching every } 6 \\
\text { weeks }\end{array}$ & $\begin{array}{l}6 \text { days of training in } \\
\text { year } 1 \text { and } 6 \text { days in } \\
\text { year } 2 \text { for tools; } 6 \text { days } \\
\text { of training in Year } 1 \text { and } \\
6 \text { days in year } 2 \text { for the } \\
\text { additional math } \\
\text { curriculum; Biweekly } \\
\text { coaching }\end{array}$ & Not reported & Not reported & $\begin{array}{l}5 \text { training sessions; } \\
\text { weekly coaching visits }\end{array}$ & $\begin{array}{l}5 \text { training sessions in } \\
\text { the first year and } 2 \\
\text { training session in the } \\
\text { second year; ongoing } \\
\text { coaching }\end{array}$ & $\begin{array}{l}\text { One half-day training; } 6 \\
\text { coaching sessions }\end{array}$ \\
\hline
\end{tabular}


TABLE 3 | Continued

\begin{tabular}{|c|c|c|c|c|c|c|c|}
\hline $\begin{array}{l}\text { Study } \\
\text { characteristics }\end{array}$ & $\begin{array}{l}\text { Tools of the Mind } \\
\text { Diamond et al., } 2007\end{array}$ & $\begin{array}{l}\text { Tools of the Mind } \\
\text { Clements et al., } 2020\end{array}$ & $\begin{array}{l}\text { Tools of the Mind } \\
\text { Lonigan and Phillips, } \\
2012\end{array}$ & $\begin{array}{l}\text { Tools of the Mind } \\
\text { Farran and Wilson, } \\
2014\end{array}$ & $\begin{array}{l}\text { Tools of the } \\
\text { Mind-CARES Study } \\
\text { Mattera et al., 2013; } \\
\text { Morris et al., } 2014\end{array}$ & $\begin{array}{l}\text { Tools of the Mind } \\
\text { Solomon et al., } 2018\end{array}$ & $\begin{array}{l}\text { Red Light/Purple } \\
\text { Light } \\
\text { McClelland et al., } \\
2019\end{array}$ \\
\hline \multicolumn{8}{|l|}{ Measures } \\
\hline Teacher practice & & & & & $\begin{array}{l}\text { Adapted teacher style } \\
\text { rating scale (TSRS) } \\
(\mathrm{OA})\end{array}$ & & \\
\hline Classroom climate & & & & & CLASS (OA) & & \\
\hline $\begin{array}{l}\text { Executive function } \\
\text { and behavioral } \\
\text { regulation }\end{array}$ & $\begin{array}{l}\text { Dots Task (DA); Flanker } \\
\text { (DA) }\end{array}$ & $\begin{array}{l}\text { Forward and backward } \\
\text { digit span (DA); HTKS } \\
\text { (DA); Peg tapping (DA) }\end{array}$ & $\begin{array}{l}\text { Behavior rating } \\
\text { inventory of executive } \\
\text { function-preschool } \\
\text { version (TR); HTKS (DA) }\end{array}$ & $\begin{array}{l}\text { Dimensional change } \\
\text { card sort (DA); copy } \\
\text { design (DA); corsi } \\
\text { block-tapping task } \\
\text { (DA); Peg tapping (DA); } \\
\text { HTKS (DA); } \\
\text { cooper-farran behavior } \\
\text { rating scales (TR); } \\
\text { Self-regulation } \\
\text { assessor rating (AR) }\end{array}$ & $\begin{array}{l}\text { Head-to-Toes (DA); } \\
\text { pencil tap (DA); } \\
\text { behavioral problem } \\
\text { index (TR) }\end{array}$ & $\begin{array}{l}\text { Day/Night task (DA); } \\
\text { head-to-toes (DA) }\end{array}$ & $\begin{array}{l}\text { HTKS (DA); day/night } \\
\text { tasks (DA) }\end{array}$ \\
\hline $\begin{array}{l}\text { Emotion knowledge } \\
\text { and social } \\
\text { problem-solving } \\
\text { skills }\end{array}$ & & & & & $\begin{array}{l}\text { Facial emotions } \\
\text { identification tasks } \\
\text { (DA); emotion situation } \\
\text { tasks (DA); challenging } \\
\text { situations task (DA) }\end{array}$ & & \\
\hline $\begin{array}{l}\text { Learning and social } \\
\text { behaviors }\end{array}$ & & & & & $\begin{array}{l}\text { Social skills rating } \\
\text { system (TR) }\end{array}$ & $\begin{array}{l}\text { Social competence and } \\
\text { behavior evaluation } \\
\text { scale (TR) }\end{array}$ & \\
\hline Academic outcomes & $\begin{array}{l}\text { One-Word-picture } \\
\text { vocabulary (DA) }\end{array}$ & & $\begin{array}{l}\text { Bracken basic } \\
\text { concepts } \\
\text { scales-revised (DA); } \\
\text { test of preschool early } \\
\text { literacy (DA) }\end{array}$ & $\begin{array}{l}\text { WJ-III Letter-word } \\
\text { identification, spelling, } \\
\text { oral comprehension, } \\
\text { picture vocabulary, } \\
\text { academic knowledge, } \\
\text { applied problems, } \\
\text { quantitative concepts } \\
\text { (DA); adaptive } \\
\text { language inventory (TR) }\end{array}$ & $\begin{array}{l}\text { WJ-III letter-word } \\
\text { identification (DA); } \\
\text { WJ-III applied problems } \\
\text { (DA); EOWPVT (DA); } \\
\text { academic rating scale } \\
\text { (TR) }\end{array}$ & $\begin{array}{l}\text { Strengths and } \\
\text { difficulties questionnaire } \\
\text { (TR); early development } \\
\text { index (TR); peabody } \\
\text { picture vocabulary (DA); } \\
\text { expressive vocabulary } \\
\text { test (DA); get ready to } \\
\text { read (DA); PTX (DA) }\end{array}$ & $\begin{array}{l}\text { WJ-III letter-word } \\
\text { identification (DA); } \\
\text { preschool early } \\
\text { numeracy screener } \\
\text { (DA) }\end{array}$ \\
\hline
\end{tabular}

$D A$, direct child assessment; TR, teacher-report; $O A$, observational assessment; $A R$, assessor-report. 
TABLE 4 | Background characteristics of the cognitive skills studies.

\begin{tabular}{|c|c|c|c|c|c|}
\hline Study characteristics & $\begin{array}{l}\text { Building Blocks } \\
\text { Clements and Sarama, } 2008\end{array}$ & $\begin{array}{l}\text { Building Blocks } \\
\text { Hofer et al., } 2013\end{array}$ & $\begin{array}{l}\text { Building Blocks-MPC study } \\
\text { Morris et al., 2016; Mattera } \\
\text { and Morris, 2017; Mattera } \\
\text { et al., } 2018\end{array}$ & $\begin{array}{l}\text { Building Blocks } \\
\text { Clements et al., } 2020\end{array}$ & $\begin{array}{l}\text { Building Blocks and OWL } \\
\text { Weiland and Yoshikawa, } 2013\end{array}$ \\
\hline Design overview & $\begin{array}{l}\text { Randomized control trial; } \\
\text { classrooms were randomized to } \\
\text { three conditions: building blocks; } \\
\text { preschool mathematics } \\
\text { curriculum; and } \\
\text { business-as-usual }\end{array}$ & $\begin{array}{l}\text { Cluster randomized control trial; } \\
\text { preschools were randomly } \\
\text { assigned to building blocks } \\
\text { intervention or business-as-usual } \\
\text { condition }\end{array}$ & $\begin{array}{l}\text { Cluster randomized trial; } \\
\text { preschool sites randomly } \\
\text { assigned to building blocks } \\
\text { intervention or business-as-usual } \\
\text { control condition }\end{array}$ & $\begin{array}{l}\text { Three-armed cluster randomized } \\
\text { control trial; classrooms randomly } \\
\text { assigned to three conditions (building } \\
\text { blocks; building blocks and } \\
\text { scaffolding self-regulation; and } \\
\text { business-as-usual control condition) }\end{array}$ & Regression discontinuity design \\
\hline Sample location & & $\begin{array}{l}\text { Buffalo, NY; Boston, MA; } \\
\text { Nashville, TN }\end{array}$ & New York City, NY & San Diego county & Boston, MA \\
\hline Sample size & $\begin{array}{l}35 \text { teachers/classrooms and } 253 \\
\text { children }\end{array}$ & $\begin{array}{l}139 \text { classrooms/teachers and } \\
1714 \text { children }\end{array}$ & $\begin{array}{l}69 \text { preschool sites, } 173 \\
\text { classrooms/teachers; } 1,389 \\
\text { children }\end{array}$ & 84 classrooms/teachers; 837 children & $\begin{array}{l}250 \text { teachers/classrooms; 2,018 } \\
\text { children }\end{array}$ \\
\hline $\begin{array}{l}\text { Child sample } \\
\text { demographics }\end{array}$ & & $\begin{array}{l}\text { Treatment condition: } 17 \% \text { White, } \\
60 \% \text { Black, } 17 \% \text { Hispanic, mean } \\
\text { age } 60 \text { months; Control } \\
\text { condition: } 57 \% \text { Black, } 15 \% \\
\text { White, } 22 \% \text { Hispanic, with mean } \\
\text { age } 60 \text { months }\end{array}$ & $\begin{array}{l}57 \% \text { Hispanic, 3\% Non-Hispanic } \\
\text { White; } 37 \% \text { Non-Hispanic Black, } \\
3 \% \text { other, with mean age of } 4.17 \\
\text { years }\end{array}$ & $\begin{array}{l}39 \% \text { Hispanic, Asian Pacific Islander } \\
18 \% \text {, African-American } 11 \% \text {, and } \\
31 \% \text { non-Hispanic White }\end{array}$ & $\begin{array}{l}41 \% \text { Hispanic, } 26 \% \text { Black, } 18 \% \\
\text { White, } 11 \% \text { Asian, and 3\% other }\end{array}$ \\
\hline \multicolumn{6}{|c|}{ Intervention characteristics } \\
\hline $\begin{array}{l}\text { Duration of } \\
\text { implementation }\end{array}$ & 2 years & 2 years & 2 years & 2 years & 2 years \\
\hline $\begin{array}{l}\text { Amount of training and } \\
\text { coaching }\end{array}$ & $\begin{array}{l}4 \text { days and 2-hour refresher } \\
\text { classes once every other month } \\
\text { and monthly coaching }\end{array}$ & $\begin{array}{l}\text { teacher training ( } 7 \text { days) and } \\
\text { coaching }\end{array}$ & $\begin{array}{l}5 \text { days of training in year } 1 \text { and } \\
\text { year } 2 \text { ( } 10 \text { days total); weekly } \\
\text { coaching }\end{array}$ & $\begin{array}{l}6 \text { days of training in year } 1 \text { and year } 2 \\
\text { and biweekly coaching }\end{array}$ & $\begin{array}{l}13 \text { days of training; weekly to } \\
\text { biweekly coaching }\end{array}$ \\
\hline \multicolumn{6}{|l|}{ Measures } \\
\hline Teacher practice & COEMET (OA) & COEMET (OA) & COEMET (OA) & COEMET (OA) & \\
\hline Classroom climate & & & CLASS (OA) & & \\
\hline $\begin{array}{l}\text { Executive function and } \\
\text { behavioral regulation }\end{array}$ & & & $\begin{array}{l}\text { Pencil tap (DA); spatial conflict } \\
\text { arrows (DA); corsi blocks (DA) }\end{array}$ & $\begin{array}{l}\text { Forward and backward digit span } \\
\text { (DA); HTKS (DA); peg tapping (DA) }\end{array}$ & $\begin{array}{l}\text { Forward digit span and backward } \\
\text { digit span (DA); dimensional change } \\
\text { card sort (DA); task orientation } \\
\text { questionnaire (AR); pencil tap (DA) }\end{array}$ \\
\hline $\begin{array}{l}\text { Emotion knowledge } \\
\text { and social } \\
\text { problem-solving skills }\end{array}$ & & & & & $\begin{array}{l}\text { Emotion recognition questionnaire } \\
\text { (DA); TOQ positive emotion (TR); TOQ } \\
\text { impulse control (TR) }\end{array}$ \\
\hline \multicolumn{6}{|c|}{ Learning and social behaviors } \\
\hline Academic outcomes & $\begin{array}{l}\text { Early mathematics assessment } \\
\text { (DA) }\end{array}$ & REMA (DA) & $\begin{array}{l}\text { ECLS-B Math assessment (DA); } \\
\text { WJ-III applied problems (DA); } \\
\text { ROWPVT (DA) }\end{array}$ & $\begin{array}{l}\text { Tools for early assessment of } \\
\text { mathematics (DA); ECLS-B math } \\
\text { (DA); EOWPVT (DA); renfrew bus } \\
\text { story (DA); phonological awareness } \\
\text { literacy screening (DA) }\end{array}$ & $\begin{array}{l}\text { Peabody picture vocabulary test (DA); } \\
\text { WJ-III applied problems and } \\
\text { letter-word identification (DA); REMA } \\
\text { (DA) }\end{array}$ \\
\hline
\end{tabular}

$D A$, direct child assessment; TR, teacher-report; OA, observational assessment; AR, assessor-report. 
self-regulation, language development, and emergent literacy skills. Teachers received weekly classroom visits and meetings with REDI consultants to promote rich language use in the classroom and positive classroom management strategies. The program was evaluated in a randomized trial involving 44 preschool classrooms in 24 Head Start centers in three Pennsylvania counties assigned to intervention or "usual practice" comparison groups. Three hundred and fifty-six 4-year-old children were assessed at the start and end of the preschool year and then followed from prekindergarten through adolescence.

Making Pre-K Count (MPC) was a rigorous large-scale randomized controlled trial of an evidence-based preschool math curriculum (Building Blocks, Clements and Sarama, 2008) and professional development (Morris et al., 2016; Mattera et al., 2018). The MPC study was designed to experimentally test whether providing enhanced preschool math experiences for children could have positive effects not only on children's math skills, but on other domains of children's functioning, both in the short- and long-run. MPC took place in 69 pre-k sites, including 173 classrooms, across public schools or communitybased organizations in New York City. Thirty-five sites were randomly assigned to receive the MPC intervention. Thirtyfour sites continued with business-as-usual pre-k practices. One thousand, three hundred eighty-nine 4-year-olds were assessed in preschool as part of the study.

These trials attempted to promote EF with very different programmatic approaches. In the following sections, we describe the different approaches preschool programs have taken to improve $\mathrm{EF}$ and the evidence around the effectiveness of those approaches. Results of these studies are described along with other studies that have taken similar approaches.

\section{APPROACHES TO SCHOOL-BASED SCHOOL READINESS INTERVENTIONS THAT MAY PROMOTE EF}

Theoretically, early flexible cognitive skills, and specifically EFs, may help bolster later academic knowledge (Blair, 2006). Accumulating research points to such early cognitive processes as important predictors of school readiness. Various facets of $\mathrm{EF}$ in the fall of the preschool year have been associated with math (Espy et al., 2004), verbal ability (Hughes, 1998; Blair and Razza, 2007), vocabulary, and literacy skills at the end of preschool (McClelland et al., 2007). The same relationship is replicated in later years; children with better learning behaviors in kindergarten have faster rates of growth in reading and math achievement through second grade, and differences in achievement between children with better and poorer learning behaviors are still evident in sixth grade (McClelland et al., 2006). Conversely, attention problems undermine effective learning, and contribute to off-task behavior, distractibility, and incomplete work, all contributing to learning delays and reduced achievement (Hughes and Kwok, 2006). Bi-directional influences are also evident, as growth in early academic skills in preschool contribute to growth in EF (Welsh et al., 2010; Clements et al., 2016).
Researchers have also hypothesized associations between early EFs and later social outcomes. Relations between executive dysfunction and poor social outcomes have been identified in such diverse groups as children with attention deficit hyperactivity disorder or conduct disorder, adults with traumatic brain injury, and preschoolers with disruptive behaviors (Pennington and Ozonoff, 1996; Hughes et al., 1998; Godfrey and Shum, 2000). Consequently, the relation between EF abilities and positive social outcomes has also been investigated. In elementary school children, EFs are positively associated with social competence and negatively predictive of problem behavior up to two years later (Riggs et al., 2006; Ciairano et al., 2007). Research with preschoolers has also found that $\mathrm{EF}$ is positively related to teacher reports of on-task behavior (Blair, 2002), delay of gratification (Carlson and Moses, 2001), and engaged learning behaviors (Brock et al., 2009). While EF and social-emotional skills do seem to be related, correlations are small and it is not clear whether EF skills are causally related to (that is, lead to) later social competence or whether the relationship is bi-directional (Sasser et al., 2015; Burchinal et al., 2020).

Associations between EF and school-related social and academic outcomes has made EF a promising additional target for school-based interventions. These programs have identified $\mathrm{EF}$ as a promising potential mechanism for subsequently or concurrently supporting social-emotional learning or academic outcomes. Those school-based interventions that identified $\mathrm{EF}$ as potential mechanism for improving school readiness fell under one of four types of approaches for improving children's skills and behaviors. While all of the approaches target domains of school readiness and teacher's practices in more than one way, each approach targets specific teacher practice or behavior pathways as a mechanism for targeting children's school readiness and, possibly, EF.

\section{Behavioral-Focused Interventions}

Research has examined the relationship between the emotional and organizational climate of preschool contexts and children's self-regulation (Hamre and Pianta, 2005; Downer et al., 2010). Positive yet firm control in a classroom may provide a safe base to support children's learning and positive behaviors (WebsterStratton et al., 2001). In behavioral-focused models, teachers set classroom routines, expectations, and discipline strategies that provide clear boundaries for children's behavior and learning. Children's relationships with teachers are key levers in this approach: teachers may help modulate children's behavior and emotions (Hoglund and Leadbeater, 2004; Chryssanthopoulou et al., 2005; Raver et al., 2007) with positive, supportive interactions; alternatively, in unregulated classrooms it has been found that teachers can reinforce children's dysregulation (Brouwers and Tomic, 2000). Through such cycles, teachers can either support or undermine children's behavioral self-regulation and, potentially, EF skills.

Supporting teachers' ability to create a positive classroom climate through consistent and supportive limit-setting was one approach to improving children's behavioral and emotional regulation (Patterson et al., 1992; Webster-Stratton, 1998). The Incredible Years Teacher Training program is one example of this type of model that focuses on strengthening 
teacher classroom management, teacher-child relationships, and concrete strategies for supporting children's own emotional and behavioral regulation (Webster-Stratton et al., 2004), and potentially, EF. Figure 1 describes the hypothesized theory of change for the Incredible Years Teacher Training program.

Versions of the Incredible Years Teacher Training program alone have been tested in four rigorous randomized controlled trials with preschoolers (Webster-Stratton et al., 2004; Raver et al., 2009; Morris et al., 2013, 2014). Table 1 presents the details of each study, its design, sample intervention characteristics, and the measures used in the study. Incredible Years Teacher Training was found to have led to improvements in positive classroom management or organization, as expected, across all 4 trials. Secondarily, Foundations of Learning (FOL) found that Incredible Years led to improvements in classroom productivity and the amount of available instructional time, although not quality of instruction in the Newark site, where these outcomes were assessed (Morris et al., 2013). The program also led to the expected improvements in children's problem behaviors in the Chicago School Readiness Project (CSRP) and FOL-Newark and Webster-Stratton et al. (2004), but not in teacher reports of problem behaviors in FOL-Chicago or Head Start CARES. Incredible Years Teacher Training led to improvements in children's learning behaviors s in Head Start CARES, CSRP, and FOL-Newark, though not FOL-Chicago. Effects on positive social behaviors were mixed, with positive effects in Head Start CARES and Webster-Stratton et al. (2004) but not FOL. Effects on EF were also mixed, with positive effects in CSRP and FOL on EF and behavioral control, but not in the larger Head Start CARES trial. Despite effects on EF and social and learning behaviors in some trials, there were no effects of Incredible Years on children's early academic skills in FOL-Chicago or Head Start CARES, but CSRP did lead to improvements in children's pre-academic skills. Table 5 summarizes the pattern of effects on teacher and child outcomes across these studies of Incredible Years.

\section{Social-Emotional Learning Interventions}

Another approach to improving children's social-emotional school readiness and, secondarily, EF, builds from social information processing theory (SIP; Crick and Dodge, 1994) and emotion theory (Izard, 2009). Social information processing theorizes that children's understanding of emotion and social problem-solving abilities help guide appropriate social responses to their peers (Hughes et al., 1998; Garner and Estep, 2001; Denham et al., 2003), and emotion theory posits that the capacity to identify and label different emotions helps guide effective emotion regulation and supports social interactions (Djambazova-Popordanoska, 2016). Evidence suggests that some children may have more difficulty in correctly identifying emotions in themselves and others or identifying socially acceptable solutions to social situations (Denham, 1997; Garner et al., 1997). A key lever in this theory involves strengthening children's explicit social-emotional skills to help them regulate their emotions and respond to challenging social situations appropriately, without misinterpreting social interactions or cues (Crick and Dodge, 1994; Raver and Spagnola, 2002). Improvements in these self-regulatory social and emotional abilities were also hypothesized to cooccur or even be underwritten by improvements in EF.

Some preschool interventions have sought to support children's social and emotional development by explicitly teaching emotional knowledge and having children practice social problem-solving skills (Lynch et al., 2004; Domitrovich et al., 2007). Preschool PATHS (Promoting Alternative Thinking Strategies; Domitrovich et al., 2007) is one example of a program using this approach that uses a scripted curriculum to directly teach children about identifying emotions, strategies for self-regulation, and positive solutions to social situations. Teachers model and support children in naming a problem, using a self-regulation strategy, and practicing social problemsolving throughout the day. Figure 2 describes the hypothesized theory of change for the Preschool PATHS and Head Start REDI programs.

Preschool PATHS has been tested in rigorous trials with preschoolers as a stand alone curriculum (Domitrovich et al., 2007; Morris et al., 2014) and in combination with a language and literacy curriculum (Head Start REDI; Bierman et al., 2008). Table 2 presents the details of each study, its design, sample intervention characteristics, and the measures used in the study. PATHS improved teachers' use of instruction of social and emotional skills as expected (Bierman et al., 2008; Morris et al., 2014). Across all three trials, PATHS led to improvements on its targeted outcomes of emotion knowledge and teacher reports of social behavior in 2 of 3 trials. PATHS also led to improvements in children's teacher-reported learning behaviors in Head Start CARES and REDI. However, PATHS only led to improvements in EF when combined with a language and literacy program (Bierman et al., 2008), with no improvements in EF in the trials of the program alone. Similarly, PATHS only lead to improvements in children's literacy skills when combined with a literacy component in REDI. Table 6 summarizes the pattern of effects on teacher and child outcomes across these studies of Preschool PATHS.

\section{Interventions That Promote Play and Direct Training}

Another approach more directly targets children's EF as a primary outcome of preschool intervention. This approach has children directly practice their EF skills, albeit in different ways.

Tools of the Mind (Bodrova and Leong, 2007; Diamond et al., 2007) has children "practice" EF throughout the school day through tasks that require the use of self-regulation. Tools' central means of practicing EF expands on children's sociodramatic play as a mechanism for using working memory to plan play, shifting between multiple roles, and inhibiting other responses in role playing (Bodrova and Leong, 2009). The Tools approach is intended to help children learn to regulate their attention and behavior and interact positively with peers (Barnett et al., 2008). Tools also comprehensively reshapes the school day, creating larger blocks of pretend play time, having teachers support children's planning of their play extensively, and removing large amounts of whole group instruction. Figure 3 


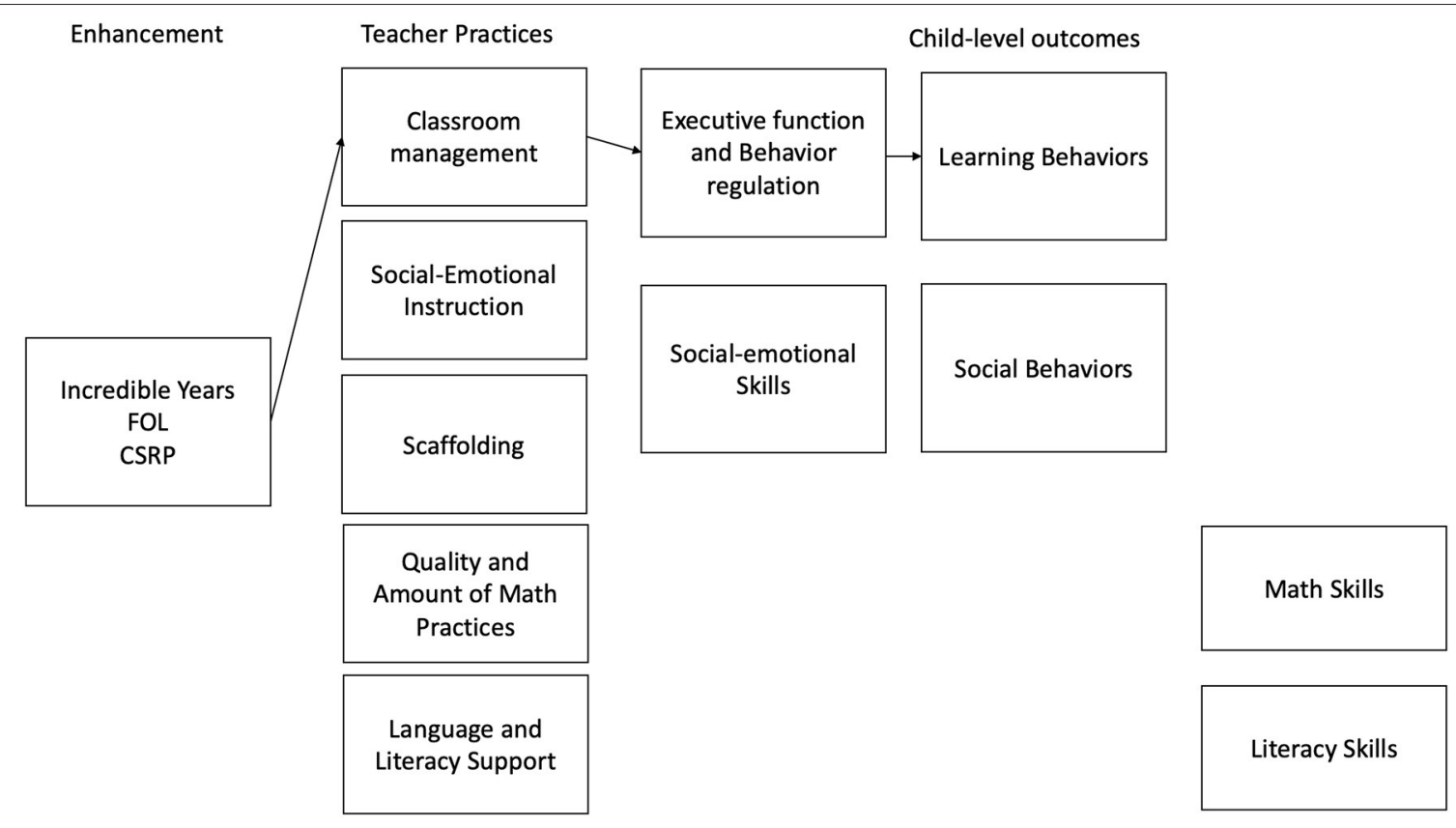

FIGURE 1 | Hypothesized theory of change for behavioral-focused interventions.

describes the hypothesized theory of change for the play components of the Tools of the Mind program.

A shortened version of Tools (Tools-Play; Morris et al., 2014) used in Head Start CARES improved teachers' scaffolding of pretend play, as expected. However, impacts on children's EF, the target of the Tools intervention, have been mixed. Six trials, described in greater detail in Table 3, have examined the effects of a version of Tools on preschool children's EF, with a smaller, earlier quasi-experimental study (Diamond et al., 2007) finding positive impacts on EF but five later randomized-controlled studies finding no evidence of program effects on EF (Clements et al., 2012; Lonigan and Phillips, 2012; Farran and Wilson, 2014; Morris et al., 2014; Solomon et al., 2018). Tools also had positive effects on children's math skills in 2 out of 5 trials where it was measured (Barnett et al., 2008; Morris et al., 2014), although the effects in the Head Start CARES trial were not corroborated across teacher reports and direct assessments. Table 7 summarizes the pattern of effects on teacher and child outcomes across these studies of Tools of the Mind.

A different way of "practicing" EF comes from direct training programs [see, for e.g., Pauli-Pott et al. (2020), Takacs and Kassai (2019)]. These interventions provide children with repeated opportunities to train on EF exercises or tasks, theorizing that short-term improvements in performance on an EF task will generalize to more global improvements in self-regulation (Posner et al., 2006). Programs use either direct EF tasks (often in more lab-based settings) or EF games (for e.g., Red Light/Purple Light; McClelland et al., 2019) to achieve this purpose. Studies demonstrate that training on a specific EF task may lead to improvements in task performance (Klingberg et al., 2002; McClelland et al., 2019; Scionti et al., 2020). However, little evidence yet exists to support that these effects lead to the hypothesized impacts on more global social or learning behaviors in a school setting (McClelland et al., 2019).

Hybrid programs that use EF games in combination with other intervention strategies have also been tested. For example, the Second Step Early Learning curriculum combined a focus on lessons that target attentional control (e.g., listening, focusing attention, using self-talk to remember, and follow directions) and Brain Builder Games that practice EF skills with lessons that focused on broader social-emotional skills, such as empathy, emotion management, friendship skills, and social problemsolving skills (Upshur et al., 2017). A small randomized trial in Head Start classrooms documented significant effects on two EF measures, although only marginally significant effects emerged on the targeted social-emotional skills (Upshur et al., 2017).

\section{Improving Cognitive Skills Related to EF}

A separate set of school readiness programs has also been found to have effects on children's EF. Unlike the other programs described above, these programs focus on children's cognitive or pre-academic skills (i.e., math and reading) instead of socialemotional development. While the main focus of these programs is on improving children's outcomes in cognitive domains, there is suggestive evidence that there may be spillover effects into EF.

Math, for example, has been viewed as a way to improve a broad set of children's competencies in additional domains, including reading, and, although evidence is less strong, language, and EF. ${ }^{2}$ Short-term improvements in math have been hypothesized to spill over across domains of children's learning into language and EF. Math experts have suggested (albeit with somewhat limited empirical evidence) that engaging with math concepts like problem solving and sequencing skills may also support working memory and inhibitory control 
TABLE 5 | The pattern of effects on teacher and child outcomes for behavioral-focused interventions.

$\begin{array}{ccccc}\begin{array}{c}\text { The incredible years } \\ \text { Webster-Stratton et al. }\end{array} & \begin{array}{c}\text { CSRP } \\ \text { (2004) }\end{array} & \begin{array}{c}\text { Foundations of } \\ \text { learning-Newark }\end{array} & \begin{array}{c}\text { Foundations of } \\ \text { learning-Chicago }\end{array} \\ & & \text { Morris et al., 2013 } & \text { Morris et al., 2013 } & \text { Mears-CARES study } \\ & & & \end{array}$

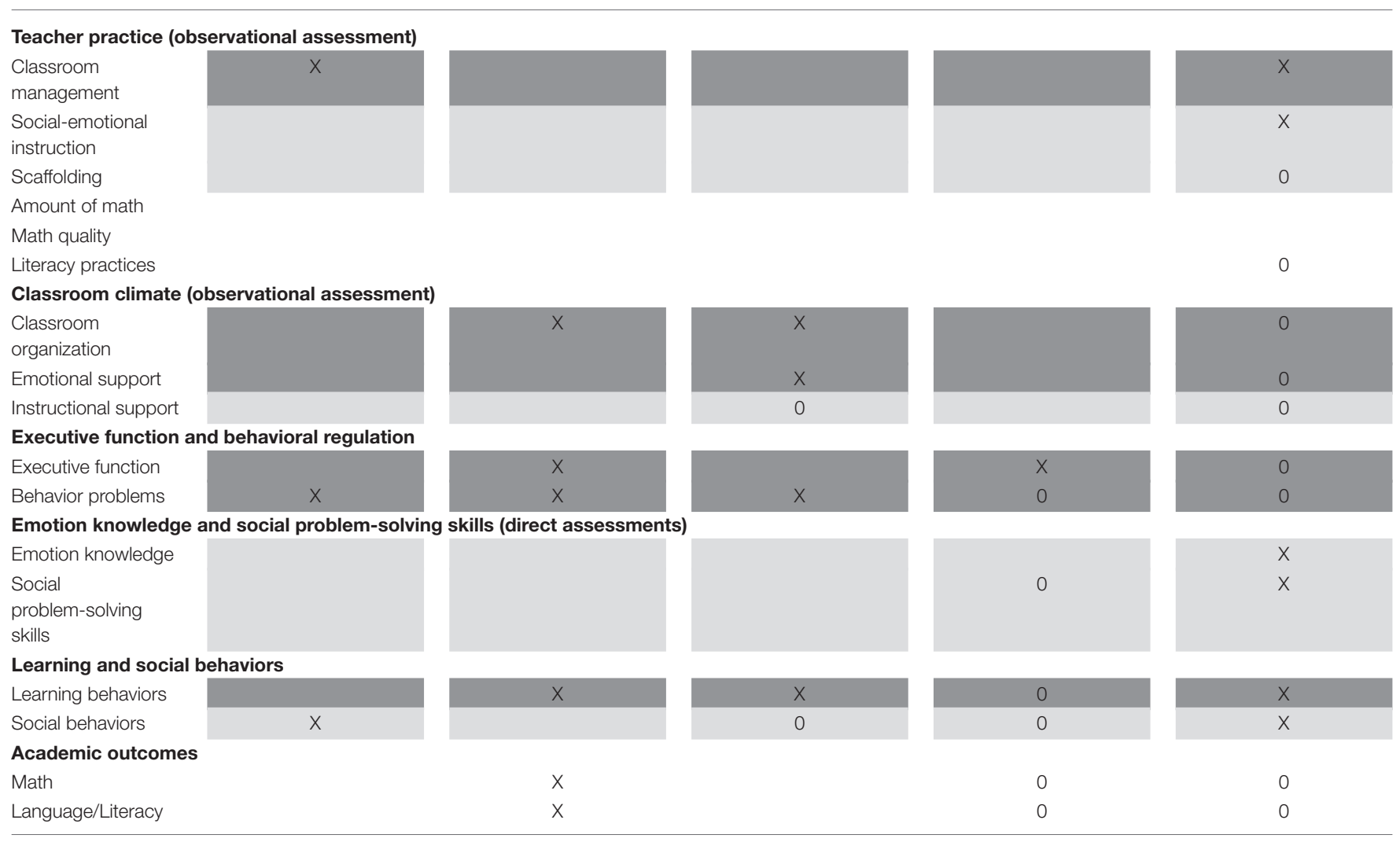

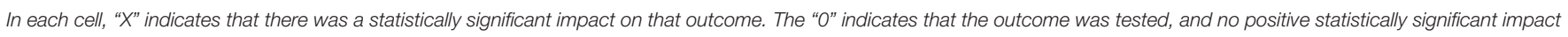

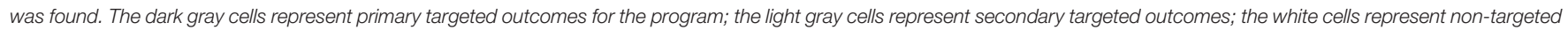
outcomes. FN represents a Kindergarten follow-up outcome.

(Blair and Razza, 2007; Blair et al., 2008). Empirical work in this area has been quite limited until recently, but a few studies from pre-k math interventions (e.g., Weiland and Yoshikawa, 2013; Clements et al., 2020) as well as from correlational research (Blair and Razza, 2007) suggesting associations between math learning and EF. Figure 4 describes the hypothesized theory of change for the Building Blocks program.

The Building Blocks' math curriculum is an evidence-based preschool math curriculum with evidence of effects on children's math skills across five large-scale randomized controlled trials in 6 sites (Clements and Sarama, 2013; Hofer et al., 2013; Morris et al., 2016; Mattera et al., 2018; Clements et al., 2020) and a study of Building Blocks plus the Opening the World of Learning (OWL) literacy curriculum using a highquality regression discontinuity design in Boston (Weiland and Yoshikawa, 2013). See Table 4 for further details about the trials. Building Blocks has been found to lead to more and higher quality math instruction in classrooms and various improvements in children's math in preschool (Clements and Sarama, 2013; Hofer et al., 2013; Weiland and Yoshikawa, 2013) or kindergarten (Mattera et al., 2018; Clements et al., 2020). Three studies have also examined whether the program might have spillover effects on children's EF. In all three studies, Building Blocks led to positive effects on children's $\mathrm{EF}$ in preschool, often that were sustained into kindergarten (Weiland and Yoshikawa, 2013; Morris et al., 2016; Mattera et al., 2018; Clements et al., 2020). Table 8 summarizes the pattern of effects on teacher and child outcomes across these studies of Building Blocks.

\section{TAKE-AWAYS}

We draw four main takeaways for the field from these studies regarding the potential to improve children's EF.

There Is Evidence That Some Preschool Approaches Do Result in Small Effects on EF, but Effects Vary by Type of Program and by Study. Some studies of early childhood interventions focused on improving school readiness do find effects on EF. Effects on EF have been found in studies of teacher's behavior management (Raver et al., 2009; Morris et al., 2013) and direct instruction on non-social-emotional learning domains (i.e., math) (Weiland and Yoshikawa, 2013; Mattera et al., 2018; Clements et al., 2020). At the same 


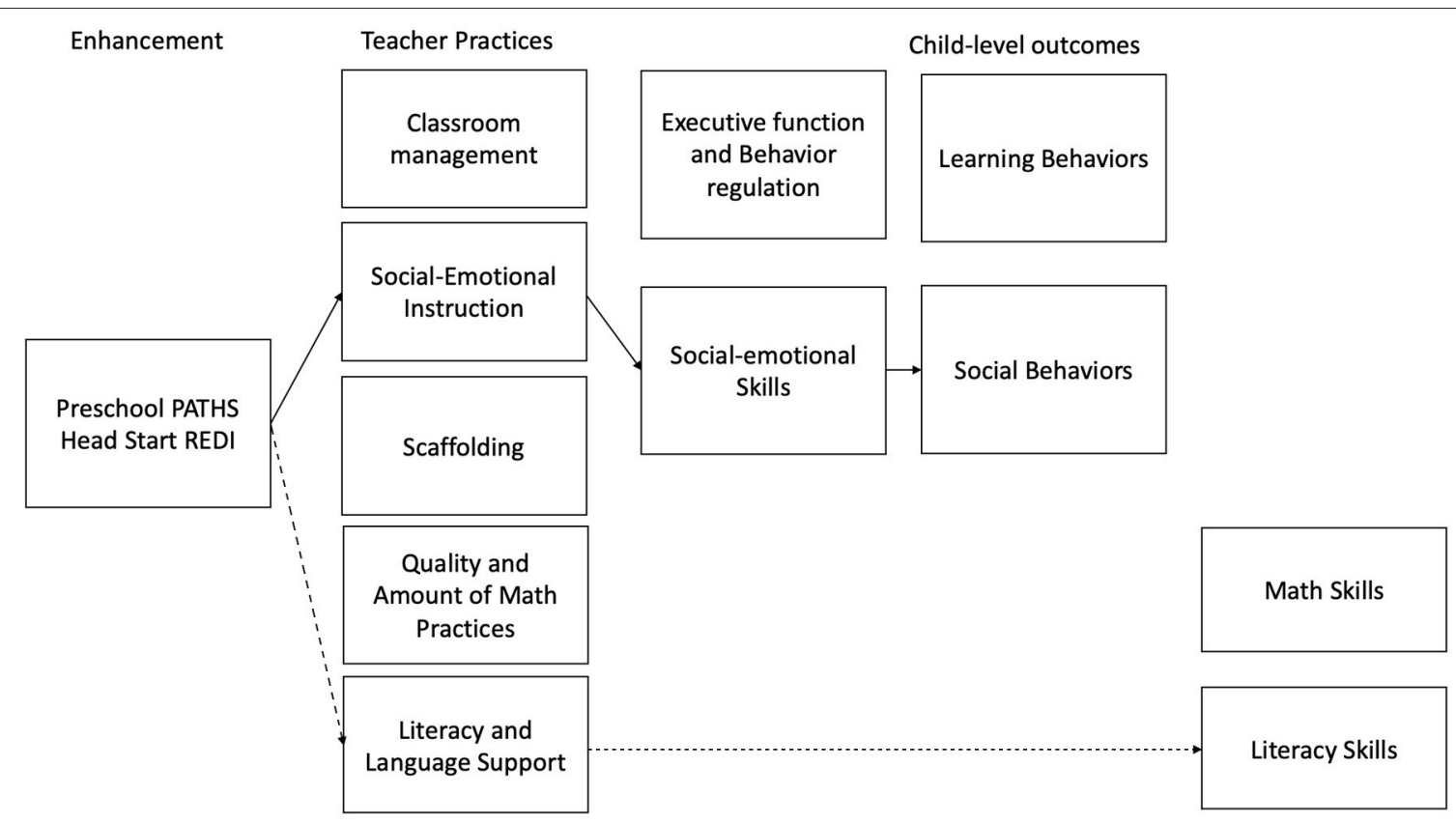

FIGURE 2 | Hypothesized theory of change for social-emotional learning interventions.

time, the larger-scale, national Head Start CARES trial that was designed to explicitly test the effects of social-emotional learning approaches on preschool children's EF did not find effects of any of the tested approaches - behavior management, direct social-emotional learning instruction, or play/trainingbased approaches - on EF in preschool (Morris et al., 2014). Moreover, effects across studies that do find effects tend to be small, and it is hard as of yet to interpret what such effects mean in the long-term for children's outcomes. While the ECE research base in this area has not been able to make sufficient progress on impact variation to understand rigorously what is contributing to these inconsistencies, in laying out the pattern of effects across these trials, we hope to stimulate hypothesis generation and further empirical work on this question.

\section{Training Teachers Directly on Supporting EF in the Classroom Is Not the Only Way to Improve Children's EF}

These studies show that it is possible to change teachers' behaviors in classrooms and improve children's social-emotional and self-regulatory outcomes, although these changes did not occur consistently across all studies. But perhaps somewhat surprisingly, training children directly in EF is not the only, or even perhaps the most effective way, to do so. Across the studies, a variety of teacher practices precipitated improvements in children's EF. For example, FOL (targeting teacher's behavior management strategies) led to improvements in teachers' classroom organization and children's EF; MPC (targeting math skills through lessons) led to improvements in teachers' math instruction and also children's EF. These changes in children's EF skills were tied to changes in the teachers' practices or in the classroom set up as a whole, not necessarily on directly teaching children explicit skills to support self-regulation or EF. Perhaps it is less about practicing EF in particular than about creating an environment that allows EF skills to develop.

\section{Measurement of EF Presents a Challenge for Studying the Effects of These Interventions on EF; Still, It Is Unlikely That the Lack of Consistent Impacts Is Solely Due to Measurement Issues Alone}

One concern raised by experts in early childhood is the relatively gross level of measurement for children's EF. Measures used to assess EF in early childhood intervention studies range from measures of behavioral regulation (e.g., teacher reports of child behavior) to behavioral measures of cognitive skills (e.g., HTKS or Pencil Tap) to more specific computerized measures of cognition (e.g., Hearts and Flowers, Arrows). And, impacts on EF from preschool programs tend to cluster in certain types of measures - particularly behavioral measures of cognitive skills rather than others (e.g., computerized cognitive measures). Over time, evidence has accumulated that measures of cognitive EF are not highly correlated with each other and with children's behavior or behavioral regulation in the classroom (Bierman et al., 2008; Morris et al., 2014). On the one hand, this suggests that how EF is measured across various ECE studies could influence the pattern of effects. On the other hand, despite the nascent and shifting characteristics of EF measures in early childhood, there are still signals that preschool programs can 
TABLE 6 | The pattern of effects on teacher and child outcomes across social-emotional learning interventions.

$\begin{array}{ccc}\text { Preschool PATHS } & \text { Preschool PATHS-CARES study } & \text { Head Start REDI } \\ \text { Domitrovich et al., 2007 } & \text { Mattera et al., 2013; Morris et al., } & \text { Bierman et al., 2008; } \\ & 2014 & \text { Domitrovich et al., 2009 }\end{array}$

Teacher practice (observational assessment)

Classroom management

Social-emotional instruction

Scaffolding
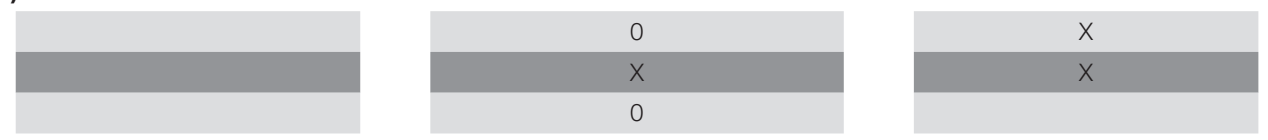

Amount of math

Math quality

Language and Literacy supports

Classroom climate (observational assessment)

Classroom organization

Emotional support

Instructional support

Executive function and behavioral regulation

Executive function

Behavior problems

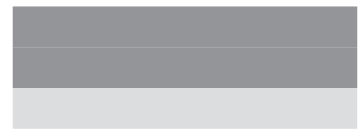

0

0

Emotion knowledge and social problem-solving skills (direct assessments)

Emotion knowledge

Social problem-solving skills

Learning and social behaviors

Learning behaviors

Social behaviors
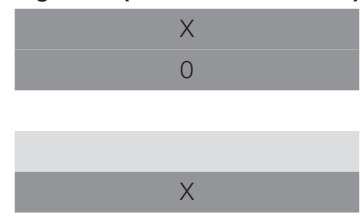

Academic outcomes

Math

Language/Literacy

0
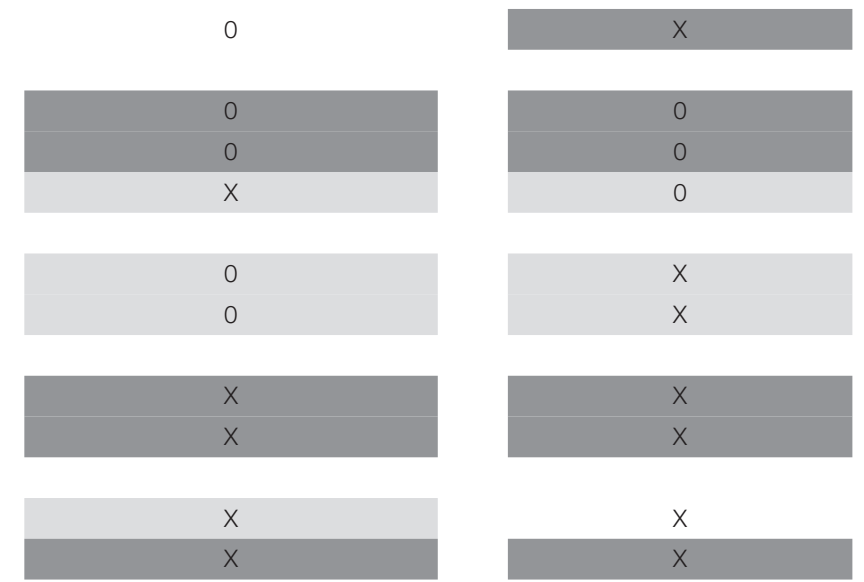

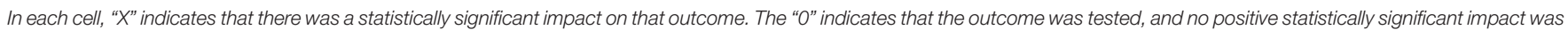

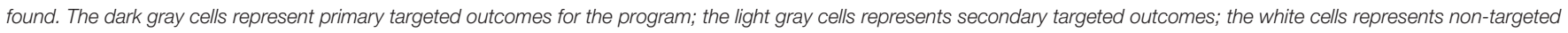
outcomes. FN represents a Kindergarten follow-up outcome.

make headway in improving children's EF to some extent, suggesting that while measurement may play a role in whether impacts are observed, it cannot be the only reason for the lack or consistent effects. Clearly, what the field needs is a comprehensive and empirically-driven theory about how different EF measures perform in measuring program impacts and how they are associated with meaningful indicators of children's behavior and achievement in the classroom. Measures with greater reliability and developmental range along with more sensitivity to change could enhance the capacity to identify effects that occur.

\section{In the Current Research Base, It Is Difficult to Disentangle Issues of Measurement, Implementation Quality, and Sample Heterogeneity, From a Lack of Evidence on the Theoretical Drivers of EF}

To ideally interpret this evidence base, all studies examining programs targeting EF in preschool would hold everything else constant, changing only the specific hypothesized driver of EF. However, studies and interventions vary in their sample, context, measurement, and the ability for the program to be implemented with high quality and fidelity. As described above, it is sometimes (though not entirely) difficult to disentangle whether a lack of impacts is due to theory, study methods, or other challenges with measurement.

\section{WHAT'S NEXT FOR THE FIELD?}

This paper summarizes a set of studies designed to test and strengthen the theory and evidence base about the possibility of improving EF in preschool children. As more findings have come out about these small but inconsistent effects, the field has stalled in developing new theories and subsequent interventions for bolstering EF. Our research over the past 15 years highlights additional questions that still remain to better establish a theoretical model of how and whether it is possible to identify preschool classroom approaches that consistently and meaningfully improve children's EF skills. Important questions about mechanisms and gaps in theory remain to be explored to better understand how and whether to target EF in young children.

\section{What Is the Right Timing of These Interventions?}

Earlier neurodevelopmental research suggested that preschool was a promising time to intervene to support EF skills due to 


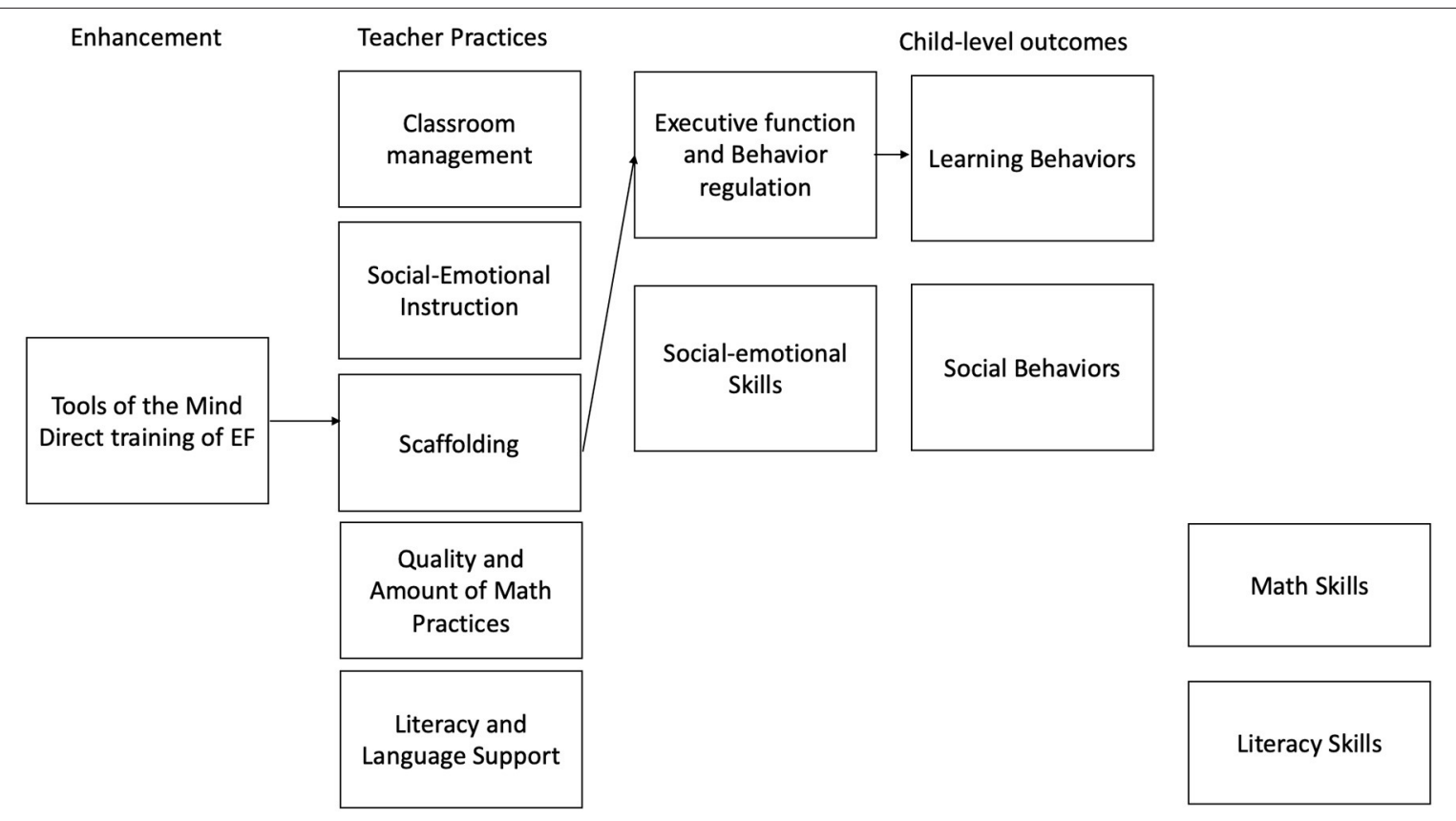

FIGURE 3 | Hypothesized theory of change for promoting play and direct training interventions.

a rapid growth from age 3 to age 5 (Blair, 2006). However, findings from studies of programs targeting EF, culminating in Head Start CARES, find small and inconsistent effects on EF skills. In contrast, a number of meta-analyses and reviews of SEL programs in elementary school consistently find positive effects on social-emotional skills, including self-regulation (e.g., Durlak et al., 2011; Corcoran et al., 2018). A handful of studies have tested in elementary school some of the programs that were inconsistently related to EF in preschool. Both a study of Tools of the Mind in kindergarten (Blair et al., 2018) and PATHS in first grade (Riggs et al., 2006) find positive program effects on EF. Interestingly, neither of those programs have consistent evidence of effects on children's EF in preschool. It is possible these programs work more effectively on EF when children have more well-developed meta-cognitive skills to utilize the selfregulatory strategies more intentionally. No empirical work to our knowledge has directly examined whether effects on EF are larger depending on the timing of intervention relative to child age and developmental stage.

\section{What Drives Effects on Children's Outcomes?}

Evidence across domains is accumulating that classroom processes and teacher practices are not as highly correlated with child outcomes as would be expected based on developmental theories and interventions (Burchinal, 2018). Similarly in the domain of EF, the evidence base to date does not clearly identify specific teacher practices that consistently are associated with changes in children's EF skills. A developing theory hypothesizes that it is the combination of teacher practices or processes and a base of content or curriculum that could lead to improvements in children's outcomes (McCormick et al., 2019). The studies described in this paper suggest that even changes in some targeted teacher practices might not be enough to improve children's EF, as in Tools of the Mind- Play (Morris et al., 2016). Instead, it is possible that content or curriculum in a specific domain are a useful vehicle for improving both teacher practices and subsequently children's EF (as in Building Blocks or REDI). Or, some integration with cognitive skill promotion could even be needed. Since EF skills are cognitive processes, it is possible that behavioral approaches are more effective when they also access and engage cognitive processes, as is done with more cognitive skill involvement.

One line of inquiry that has emerged in the wake of these studies is whether there are small, discrete teacher practices or packets of knowledge in the domain of EF that can be used without the need for a more complete EF curriculum [for e.g., Jones et al. (2017) description of "kernels"]. In other words, are there specific teacher instructional practices that can be identified, in the absence of curriculum, that directly improve children's EF? This theory posits that there are universal practices in a given domain that teachers can do to improve children's outcomes in that domain. However, the evidence base reviewed in this paper does not clearly identify if such kernels exist in the service of moving child outcomes in the domain of EF. Furthermore, an open question still remains about whether it is possible to change teachers' practice or knowledge in this way, disconnected from a curriculum.

\section{What Is the Relationship Between EF and Other Outcomes?}

The evidence reviewed in this paper also suggests that more careful attention needs to be paid to explaining and defining the relationship between EF and other outcomes. Open questions remain about the added value of EF compared to classroom 
TABLE 7 | The pattern of effects on teacher and child outcomes across promoting play and direct training interventions.

\begin{tabular}{|c|c|c|c|c|c|c|}
\hline $\begin{array}{l}\text { Tools of the mind } \\
\text { Diamond et al., } 2007\end{array}$ & $\begin{array}{c}\text { Tools of the mind } \\
\text { Clements et al., } \\
2012\end{array}$ & $\begin{array}{l}\text { Tools of the mind } \\
\text { Lonigan and } \\
\text { Phillips, } 2012\end{array}$ & $\begin{array}{c}\text { Tools of the mind } \\
\text { Farran and Wilson, } \\
2014\end{array}$ & $\begin{array}{l}\text { Tools of the } \\
\text { mind-Play-CARES study } \\
\text { Mattera et al., 2013; } \\
\text { Morris et al., 2014 }\end{array}$ & $\begin{array}{l}\text { Tools of the mind } \\
\text { Solomon et al., } 2018\end{array}$ & $\begin{array}{l}\text { Red light/purple light } \\
\text { McClelland et al., } 2019\end{array}$ \\
\hline
\end{tabular}

\section{Teacher practice (observational assessment)}

Classroom

management

Social-emotional

instruction

Scaffolding
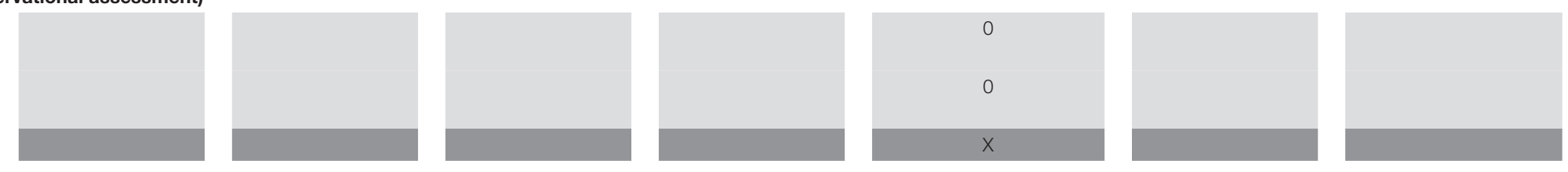

Math quality

Language and literacy

supports

Classroom climate (observational assessment)

Classroom organization

Emotional support

Instructional suppor

Executive function and behavioral regulation

Executive function

Behavior problems
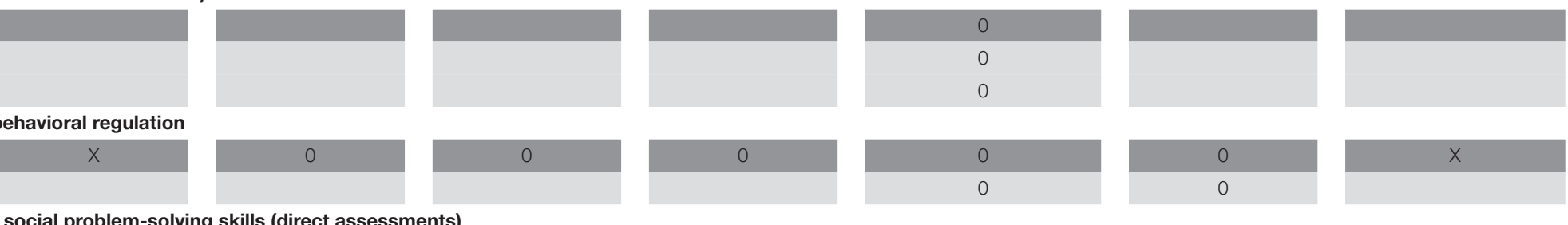

Emotion knowledge and social problem-solving skills (direct assessments)

Emotion knowledge

Social problem-solving

skills
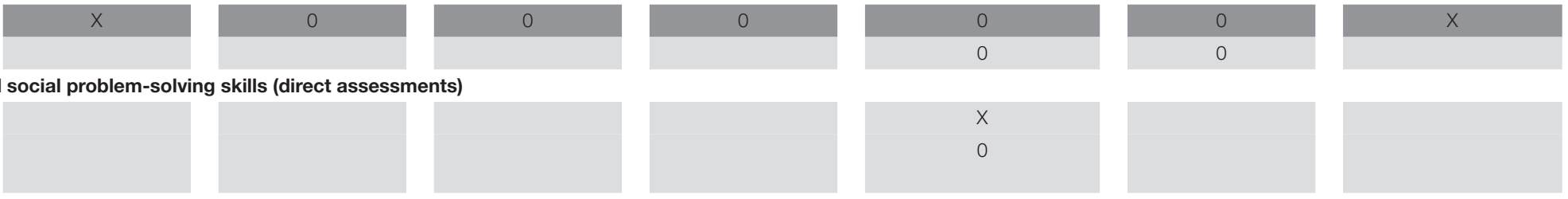

Learning behaviors

Social behaviors
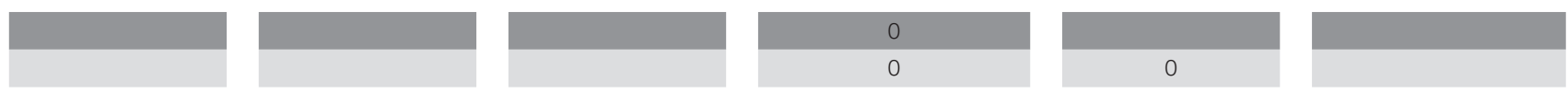

Math

0

0

Language/Literacy

0

$x$

0

X

In each cell, "X" indicates that there was a statistically significant impact on that outcome. The "O" indicates that the outcome was tested, and no positive statistically significant impact was found. The dark gray cells represent primary targeted outcomes for the program; the light gray cells represents secondary targeted outcomes; the white cells represents non-targeted outcomes. FN represents a Kindergarten follow-up outcome. 


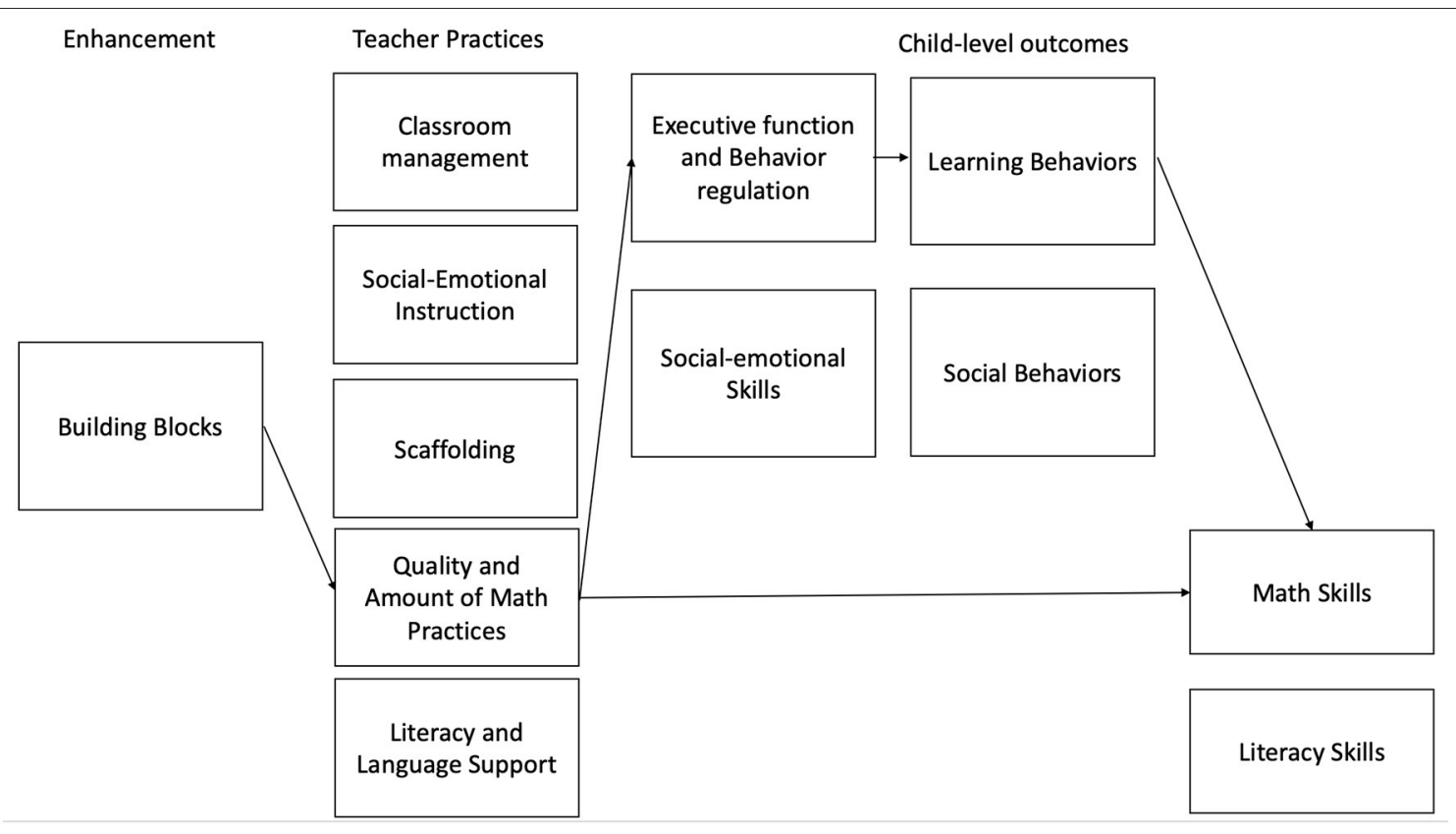

FIGURE 4 | Hypothesized theory of change for cognitive skills interventions.

behavioral measures such as approaches to learning. Some studies examining similar EF-targeted programs have found program effects on EF, while others have found positive effects on approaches to learning. It is not clear why this might be and what these effects may mean for longer-term learning. Both the evidence and theory are similarly murky about the directionality of associations. Based on longitudinal research looking at early EF's relation with later outcomes, the presumption has been that improving EF first will promote cognitive and behavioral regulation second. But, several studies suggest that gains in academic skill influence subsequent EF growth (Welsh et al., 2010; Clements et al., 2016). And, other studies suggest that programs targeted at other domains of learning such as math may be equally as capable of moving $\mathrm{EF}$, and also improve performance in other domains as well (Rabiner et al., 2010; Mattera et al., 2018; Clements et al., 2020). It is possible that learning new content and reasoning in new ways about literacy or mathematical challenges may promote EF growth as much as reflect it. Further research is needed to more rigorously disentangle the relationship between EF and regulation.

\section{What Role Does Scale Play in the Ability to Improve EF?}

Many of the original studies that launched FOL, CARES, and MPC were smaller efficacy trials that worked closely with or were directly led by the developers of the interventions in one site or context. EF effects were found in many of these trials, in which levels of hands-on support of teachers was very high. In contrast, Head Start CARES scaled many of these programs up, testing them in over 300 classrooms around the country.
In general, effects from interventions tend to be smaller and more diffuse when implemented on a larger scale (Wolf et al., 2020). While it is unclear why this is so, smaller focused studies run by developers may incorporate more implicit tailoring or adjusting the intervention approach to the specific location they are working, whereas larger studies generalize the approach across diverse settings.

It is also possible that different approaches may work more or less effectively in different contexts or with different subgroups of children. Many of the large-scale trials we describe in this article expanded the evaluation of these programs into other populations, including children from low-income families, racially or ethnically diverse samples, and various contexts (e.g., rural, urban). Variation in sample composition and children's individual differences may influence the pattern of effects from various evaluations. For example, some studies of programs targeting EF have found evidence of larger effects in children entering preschool with lower EF skills (Red Light, Purple Light and REDI; McClelland et al., 2019).

Twenty years ago, the early childhood intervention field sought to understand the promise and importance of EF for children's social and cognitive development. A set of rigorous trials have begun to unpack possible ways to support preschoolers' EF skills in the classroom, highlighting some approaches that have demonstrated success across multiple studies while identifying other approaches that have failed to consistently lead to improved EF. Yet, large questions remain for the field about the causal role EF plays in supporting later achievement and behavior, the appropriate timing for intervention, the teacher practices that support EF skills, and the measurement of EF. 
TABLE 8 | The pattern of effects on teacher and child outcomes across cognitive skills interventions.

$\begin{array}{cccc}\text { Building blocks } & \text { Building blocks } & \text { Building blocks-MPC study } & \text { Building blocks } \\ \begin{array}{c}\text { Clements et al., 2011; Sarama } \\ \text { et al., 2012 }\end{array} & \text { Hofer et al., 2013 } & \text { and Morris, 2017; Mattera } & \text { Clements et al., 2020 } \\ & & \text { et al., 2018 } & \text { Weiland and Yoshikawa, 2013 } \\ & & \end{array}$

\section{Teacher practice (observational assessment)}

Classroom

management

Social-emotional

instruction

Scaffolding

Amount of math

Math quality
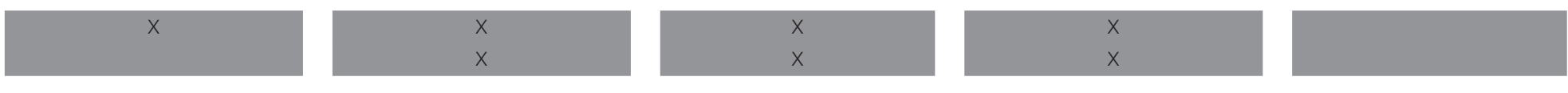

Language and literacy

supports

Classroom climate (observational assessment)

Classroom organization

Emotional support

Instructional support

Executive function and behavioral regulation

Executive function

Behavior problems

Emotion knowledge and social problem-solving skills (direct assessments)

Emotion knowledge
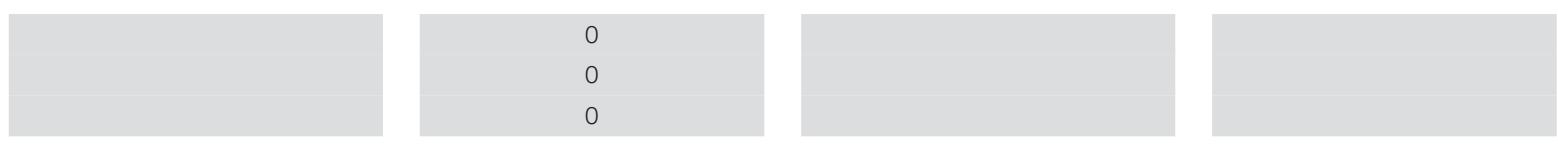

Social problem-solving

skills

Learning and social behaviors

Learning behaviors

Social behaviors

\section{Academic outcomes}

Math

Language/Literacy

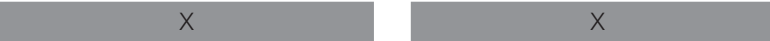

In each cell, "X" indicates that there was a statistically significant impact on that outcome. The dark gray cells represent primary targeted outcomes for the program; the light gray cells represents secondary targeted outcomes; the white cells represents non-targeted outcomes. FN represents a Kindergarten follow-up outcome. 


\section{AUTHOR CONTRIBUTIONS}

SM wrote the manuscript. NR, PM, and $\mathrm{KB}$ revised the manuscript. All authors contributed to the article and approved the submitted version.

\section{FUNDING}

The Making Pre-K Count study was made possible by a partnership between Robin Hood, one of the country's leading antipoverty organizations based in New York City, and MDRC. Additional funding was provided by the Heising-Simons Foundation, the Overdeck Family Foundation, and the Richard

\section{REFERENCES}

Barnett, W. S., Jung, K., Yarosz, D. J., Thomas, J., Hornbeck, A., Stechuk, R., et al. (2008). Educational effects of the tools of the mind curriculum: a randomized trial. Early Childh. Res. Q. 23, 299-313. doi: 10.1016/j.ecresq.2008.03.001

Bierman, K. L., Domitrovich, C. E., Nix, R. L., Gest, S. D., Welsh, J. A., Greenberg, M. T., et al. (2008). Promoting academic and social-emotional school readiness: the head start REDI program. Child Dev. 79, 1802-1817. doi: 10.1111/j.1467-8624.2008.01227.x

Blair, C. (2002). School readiness: integrating cognition and emotion in a neurobiological conceptualization of children's functioning at school entry. Am. Psychol. 57, 111-127. doi: 10.1037/0003-066X.57.2.111

Blair, C. (2006). How similar are fluid cognition and general intelligence? A developmental neuroscience perspective on fluid cognition as an aspect of human cognitive ability. Behav. Brain Sci. 29, 109-125. doi: 10.1017/S0140525X06009034

Blair, C., Knipe, H., and Gamson, D. (2008). Is there a role for executive functions in the development of mathematics ability? Mind Brain Educ. 2, 80-89. doi: 10.1111/j.1751-228X.2008.00036.x

Blair, C., McKinnon, R. D., and Daneri, M. P. (2018). Effect of the tools of the mind kindergarten program on children's social and emotional development. Early Childh. Res. Q. 43, 52-61.

Blair, C., and Razza, R. P. (2007). Relating effortful control, executive function, and false belief understanding to emerging math and literacy ability in kindergarten. Child Dev. 78, 647-663. doi: 10.1016/j.ecresq.2018.01.002

Bodrova, E., Leong, D. J. (2006) Tools of the Mind: The Vygotskian Approach to Early Childhood Education. Pearson (2006).

Bodrova, E., and Leong, D. J. (2007). "Play and early literacy: a vygotskian approach,” In: Edited by Kathleen A. Roskos, James F. Christie. Play and Literacy in Early Childhood: Research From Multiple Perspectives (Boca Raton, FL: Routledge), 185-200.

Bodrova, E., and Leong, D. J. (2009). Tools of the Mind: The Vygotskian Approach to Early Childhood Education. 2nd Edn. Upper Saddle River, NJ: Prentice-Hall.

Brock, L. L., Rimm-Kaufman, S. E., Nathanson, L., and Grim, K. J. (2009). The contributions of "hot" and "cool" executive function to children's academic achievement, learning-related behaviors, and engagement in kindergarten. Early Childh. Res. Q. 24, 337-349. doi: 10.1016/j.ecresq.2009.06. 001

Brouwers, A., and Tomic, W. (2000). A longitudinal study of teacher burnout and perceived self-efficacy in classroom management. Teach. Teach. Educ. 16, 239-253. doi: 10.1016/S0742-051X(99)00057-8

Burchinal, M. (2018). Measuring early care and education quality. Child Dev. Perspect. 12, 3-9. doi: 10.1111/cdep.12260

Burchinal, M., Foster, T. J., Garber, K., Bezdek, K. G.,Bratsch-Hines, M., Blair, C., et al. (2020). School-entry skills predicting school-age academic and social-emotional trajectories. Early Childh. Res. Q. 51, 67-80. doi: 10.1016/j.ecresq.2019.08.004
W. Goldman Family Foundation. The Head Start CARES study was conducted by MDRC and sponsored by the Office of Head Start and the Office of Planning, Research and Evaluation (OPRE) in the Administration for Children and Families (ACF), U.S. Department of Health and Human Services (HHS). The Foundations of Learning study was conducted by MDRC and funded by the George Gund Foundation, the Grable Foundation, the John D. and Catherine T. MacArthur Foundation, the Joyce Foundation, the Kresge Foundation, the McCormick Foundation, the Nicholson Foundation, the Pew Charitable Trusts, and the Robert Wood Johnson Foundation. The Head Start REDI was supported by Grant No. R01HD046064 from the National Institute on Child Health and Human Development.

Carlson, S. M. (2005). Developmentally sensitive measures of executive function in preschool children. Dev. Neuropsychol. 28, 595-616. doi: 10.1207/s15326942dn2802_3

Carlson, S. M., and Moses, L. J. (2001). Individual differences in inhibitory control and children's theory of mind. Child Dev. 72, 1032-1053. doi: $10.1111 / 1467-8624.00333$

Chryssanthopoulou, C. C., Turner-Cobb, J. M., Lucas, A., and Jessop, D. (2005). Childcare as a stabilizing influence on HPA axis functioning: a reevaluation of maternal occupational patterns and familial relations. Dev. Psychobiol. 47, 354-368. doi: 10.1002/dev.20100

Ciairano, S., Visu-Petra, L., and Settanni, M. (2007). Executive inhibitory control and cooperative behavior during early school years: a follow-up study. J. Abnorm. Child Psychol. 35, 335-345. doi: 10.1007/s10802-006-9094-z

Clements, D. H., and Sarama, J. (2008). Experimental evaluation of the effects of a research-based preschool mathematics curriculum. Am. Educ. Res. J. 45, 443-494. doi: 10.3102/0002831207312908

Clements, D. H. and Sarama, J. (2013). Building Blocks: Teacher?s Edition Columbus, OH: McGraw-Hill.

Clements, D. H., Sarama, J., Layzer, C., Unlu, F., and Fesler, L. (2020). Effects on mathematics and executive function of a mathematics and play intervention versus mathematics alone. J. Res. Math. Educ. 51, 301-333. doi: 10.5951/jresemtheduc-2019-0069

Clements, D. H., Sarama, J., Layzer, C., Unlu, F., Wolfe, C. B., Spitler, M. E., et al. (2016). Effects of TRIAD on Mathematics Achievement: Long-Term Impacts. Society for Research on Educational Effectiveness, Evanston, IL.

Clements, D. H., Sarama, J., Spitler, M. E., Lange, A. A., and Wolfe, C. B. (2011). Mathematics learned by young children in an intervention based on learning trajectories: A large-scale cluster randomized trial. J. Res. Math. Educat. JRME. 42(2):127-166. doi: 10.5951/jresematheduc.42.2.0127

Clements, D. H., Sarama, J., Unlu, F., and Layzer, C. (2012). The Efficacy of an Intervention Synthesizing Scaffolding Designed to Promote Self-Regulation with an Early Mathematics Curriculum: Effects on Executive Function. Society for Research on Educational Effectiveness, Evanston, IL.

Corcoran, R. P., Cheung, A. C., Kim, E., and Xie, C. (2018). Effective universal school-based social and emotional learning programs for improving academic achievement: a systematic review and meta-analysis of 50 years of research. Educ. Res. Rev. 25, 56-72. doi: 10.1016/j.edurev.2017.12.001

Crick, N. R., and Dodge, K. A. (1994). A review and reformulation of social information-processing mechanisms in children's social adjustment. Psychol. Bull. 115, 74-101. doi: 10.1037/0033-2909.115.1.74

Denham, S. A. (1997). "When I have a Bad Dream, Mommy Holds Me": preschoolers' conceptions of emotions, parental socialization, and emotional competence. Int. J. Behav. Dev. 20, 301-319. doi: 10.1080/01650259738 5351

Denham, S. A., Blair, K. A., DeMulder, E., Levitas, J., Sawyer, K., AuerbachMajor, S., et al. (2003). Preschool emotional competence: pathway to social competence? Child Dev. 74, 238-256. doi: 10.1111/1467-8624.00533 
Diamond, A., Barnett, W. S., Thomas, J., and Munro, S. (2007). Preschool program improves cognitive control. Science 318, 1387-1388. doi: $10.1126 /$ science. 1151148

Djambazova-Popordanoska, S. (2016). Implications of emotion regulation on young children's emotional wellbeing and educational achievement. Educ. Rev. 68, 497-515. doi: 10.1080/00131911.2016.1144559

Domitrovich, C. E., Cortes, R. C., Anand, D., and Greenberg, M. T. (2007), Improving young children's social and emotional competence: a randomized trial of the preschool "PATHS" curriculum. J. Prim. Prevent. 28, 67-91. doi: 10.1007/s10935-007-0081-0

Domitrovich, C. E., Gest, S. D., Gill, S., Bierman, K. L., Welsh, J., and Jones, D. (2009). Fostering high quality teaching with an enriched curriculum and professional development support: the head start REDI program. Am. Educ. Res. J. 46, 567-597. doi: 10.3102/0002831208328089

Downer, J., Sabol, T. J., and Hamre, B. (2010). Teacher-child interactions in the classroom: Toward a theory of within-and cross-domain links to children's developmental outcomes. Early Educ. Dev. 21, 699-723. doi: 10.1080/10409289.2010.497453

Durlak, J. A., Weissberg, R. P., Dymnicki, A. B., Taylor, R. D., and Schellinger, K. B. (2011). The impact of enhancing students' social and emotional learning: A meta-analysis of school-based universal interventions. Child Dev. 82, 405-432. doi: 10.1111/j.1467-8624.2010.01564.x

Espy, K. A., McDiarmid, M. M., Cwik, M. F., Stalets, M. M., Hamby, A., and Senn, T. E. (2004). The contribution of executive functions to emergent mathematic skills in preschool children. Dev. Neuropsychol. 26, 465-486. doi: 10.1207/s15326942dn2601_6

Farran, D. C., and Wilson, S. J. (2014). Achievement and Self-Regulation in PreKindergarten Classrooms: Effects of the Tools of the Mind Curriculum. Nashville, TN: Vanderbilt University.

Garner, P. W., and Estep, K. M. (2001). Emotional competence, emotion socialization, and young children's peer-related social competence. Early Educ. Dev. 12, 29-48. doi: 10.1207/s15566935eed1201_3

Garner, P. W., Jones, D. C., Gaddy, G., and Rennie, K. M. (1997). Lowincome mothers' conversations about emotions and their children's emotional competence. Soc. Dev. 6, 37-52. doi: 10.1111/j.1467-9507.1997.tb00093.x

Garon, N., Bryson, S. E., and Smith, I. M. (2008). Executive function in preschoolers: a review using an integrative framework. Psychol. Bull. 134, 31-60. doi: 10.1037/0033-2909.134.1.31

Godfrey, H. P., and Shum, D. (2000). Executive functioning and the application of social skills following traumatic brain injury. Aphasiology 14, 433-444. doi: 10.1080/026870300401441

Hamre, B. K., and Pianta, R. C. (2005). Can instructional and emotional support in the first-grade classroom make a difference for children at risk of school failure? Child Dev. 76, 949-967. doi: 10.1111/j.1467-8624.2005.00889.x

Hofer, K. G., Lipsey, M. W., Dong, N., and Farran, D. C. (2013). Results of the Early Math Project: Scale-Up Cross-Site Results. Nashville, TN: Vanderbilt University.

Hoglund, W. L., and Leadbeater, B. J. (2004). The effects of family, school, and classroom ecologies on changes in children's social competence and emotional and behavioral problems in first grade. Dev. Psychol. 40, 533-544. doi: 10.1037/0012-1649.40.4.533

Hughes, C. (1998). Executive function in preschoolers: links with theory of mind and verbal ability. Br. J. Dev. Psychol. 16, 233-253. doi: 10.1111/j.2044-835X.1998.tb00921.x

Hughes, C., Dunn, J., and White, A. (1998). Trick or treat?: Uneven understanding of mind and emotion and executive dysfunction in "hard-to-manage" preschoolers. J. Child Psychol. Psychiatry 39, 981-994. doi: 10.1111/1469-7610.00401

Hughes, C., and Graham, A. (2002). Measuring executive functions in childhood: Problems and solutions? Child Adolesc. Ment. Health 7, 131-142. doi: 10.1111/1475-3588.00024

Hughes, J. N., and Kwok, O. M. (2006). Classroom engagement mediates the effect of teacher-student support on elementary students' peer acceptance: a prospective analysis. J. School Psychol. 43, 465-480. doi: 10.1016/j.jsp.2005.10.001

Izard, C. E. (2009). Emotion theory and research: highlights, unanswered questions, and emerging issues. Ann. Rev. Psychol. 60, 1-25. doi: 10.1146/annurev.psych.60.110707.163539
Jacob, R., and Parkinson, J. (2015). The potential for school-based interventions that target executive function to improve academic achievement: a review. Rev. Educat. Res. 85, 512-552. doi: 10.3102/00346543145 61338

Jones, S., Bailey, R., Brush, K., and Kahn, J. (2017). Kernels of Practice for SEL: Low-Cost, Low-Burden Strategies. New York, NY: The Wallace Foundation.

Klingberg, T., Forssberg, H., and Westerberg, H. (2002). Training of working memory in children with ADHD. J. Clin. Exp. Neuropsychol. 24, 781-791. doi: $10.1076 /$ jcen.24.6.781.8395

Lonigan, C. J., and Phillips, B. M. (2012). Comparing Skills-Focused and SelfRegulation Focused Preschool Curricula: Impacts on Academic and SelfRegulatory Skills. Society for Research on Educational Effectiveness, Evanston, IL.

Lynch, K. B., Geller, S. R., and Schmidt, M. G. (2004). Multi-year evaluation of the effectiveness of a resilience-based prevention program for young children. J. Prim. Prevent. 24, 335-353. doi: 10.1023/B:JOPP.0000018052.12488.d1

Mattera, S., Jacob, R., and Morris, P. (2018). Strengthening Children's Math Skills With Enhanced Instruction: The Impacts of Making Pre-K Count and High $5 \mathrm{~s}$ on Kindergarten Outcomes. New York, NY: MDRC.

Mattera, S. and Morris, P. (2017). Counting on Early Math Skills: Preliminary Kindergarten Impacts of the Making Pre-K Count and High 5 s Programs. New York, NY: MDRC.

Mattera, S. K., Lloyd, C. M., Fishman, M., and Bangser, M. (2013). A First Look at the Head Start CARES Demonstration: Large-Scale Implementation of Programs to Improve Children's Social-Emotional Competence. OPRE Report 2013-47 (New York, NY: MDRC).

McClelland, M. M., Acock, A. C., and Morrison, F. J. (2006). The impact of kindergarten learning-related skills on academic trajectories at the end of elementary school. Early Childh. Res. Q. 21, 471-490. doi: 10.1016/j.ecresq.2006.09.003

McClelland, M. M., Cameron, C. E., Connor, C. M., Farris, C. L., Jewkes, A. M., and Morrison, F. J. (2007). Links between behavioral regulation and preschoolers' literacy, vocabulary, and math skills. Dev. Psychol. 43, 947. doi: 10.1037/0012-1649.43.4.947

McClelland, M. M., Tominey, S. L., Schmitt, S. A., Hatfield, B., Purpura, D., Gonzales, C., et al. (2019). Red light, purple light! Results of an intervention to promote school readiness for children from low-income backgrounds. Front. Psychol. 10:2365. doi: 10.3389/fpsyg.2019.02365

McCormick, M., Mattera, S., and Hsueh, J. (2019). Preschool to Third Grade Alignment: What Do We Know and What Are We Learning? Policy Brief. New York, NY: MDRC.

Morris, P., Lloyd, C. M., Millenky, M., Leacock, N., Raver, C. C., and Bangser, M. (2013). Using Classroom Management to Improve Preschoolers' Social and Emotional Skills: Final Impact and Implementation Findings From the Foundations of Learning Demonstration in Newark and Chicago. New York, NY: MDRC.

Morris, P., Mattera, S., Castells, N., Bangser, M., Bierman, K., and Raver, C. C. (2014). Impact Findings From the Head Start CARES Demonstration: National Evaluation of Three Approaches to Improving Preschoolers' Social and Emotional Competence. Washington, DC: OPRE Report.

Morris, P. A., Mattera, S. K., and Maier, M. F. (2016). Making Pre-K Count: Improving Math Instruction in New York City. New York, NY: MDRC.

Noble, K. G., McCandliss, B. D., and Farah, M. J. (2007). Socioeconomic gradients predict individual differences in neurocognitive abilities. Dev. Sci. 10, 464-480. doi: 10.1016/j.drugalcdep.2007.10.015

Patterson, G. R., Reid, J. B., and Dishion, T. J. (1992). Antisocial Boys, Vol. 4. Eugene, OR: Castalia Pub Co.

Pauli-Pott, U., Mann, C., and Becker, K. (2020). Do cognitive interventions for preschoolers improve executive functions and reduce ADHD and externalizing symptoms? A meta-analysis of randomized controlled trials. Eur. Child Adolesc. Psychiatry. doi: 10.1007/s00787-020-01627-z

Pennington, B. F., and Ozonoff, S. (1996). Executive functions and developmental psychopathology. J. Child Psychol. Psychiatry 37, 51-87. doi: 10.1111/j.1469-7610.1996.tb01380.x

Posner, M. I., Sheese, B. E., Odluda,ş, Y., and Tang, Y. (2006). Analyzing and shaping human attentional networks. Neural Netw. 19, 1422-1429. doi: 10.1016/j.neunet.2006.08.004 
Rabiner, D. L., Murray, D. W., Skinner, A. T., and Malone, P. S. (2010). A randomized trial of two promising computer-based interventions for students with attention difficulties. J. Abnorm. Child Psychol. 38, 131-142. doi: 10.1007/s10802-009-9353-x

Raver, C. C. (2002). Emotions matter: Making the case for the role of young children's emotional development for early school readiness. Soc. Policy Rep. 16, 1-20. doi: 10.1002/j.2379-3988.2002.tb00041.x

Raver, C. C., Gershoff, E. T., and Aber, J. L. (2007). Testing equivalence of mediating models of income, parenting, and school readiness for white, black, and hispanic children in a national sample. Child Dev. 78, 96-115. doi: 10.1111/j.1467-8624.2007.00987.x

Raver, C. C., Jones, S. M., Li-Grining, C., Zhai, F., Bub, K., and Pressler, E. (2011). CSRP's impact on low-income preschoolers' preacademic skills: self-regulation as a mediating mechanism. Child Dev. 82, 362-378. doi: $10.1111 / j .1467-8624.2010 .01561 . x$

Raver, C. C., Jones, S. M., Li-Grining, C., Zhai, F., Metzger, M. W., and Solomon, B. (2009). Targeting children's behavior problems in preschool classrooms: a cluster-randomized controlled trial. J. Consult. Clin. Psychol. 77, 302. doi: $10.1037 / \mathrm{a} 0015302$

Raver, C. C., Jones, S. M., Li-Grining, C. P., Metzger, M., Champion, K. M., and Sardin, L. (2008). Improving preschool classroom processes: preliminary findings from a randomized trial implemented in Head Start settings. Early Childh. Res. Q. 23, 10-26. doi: 10.1016/j.ecresq.2007.09.001

Raver, C. C., and Spagnola, M. (2002). When my mommy was angry, I was speechless: Children's perceptions of maternal emotional expressiveness within the context of economic hardship. Marr. Family Rev. 34, 63-88. doi: 10.1300/J002v34n01_04

Riggs, N. R., Jahromi, L. B., Razza, R. P., Dillworth-Bart, J. E., and Mueller, U. (2006). Executive function and the promotion of social-emotional competence. J. Appl. Dev. Psychol. 27, 300-309. doi: 10.1016/j.appdev.2006.04.002

Sarama, J., Lange, A., Clements, D.H. and Wolfe, C.B. (2012). The impacts of an early mathematics curriculum on oral language and literacy. Early Childhood Res. Quarter. 27, 489-502. doi: 10.1016/j.ecresq.2011.12.002

Sasser, T. R., Bierman, K. L., and Heinrichs, B. (2015). Executive functioning and school adjustment: the mediational role of pre-kindergarten learning-related behaviors. Early Childh. Res. Q. 30, 70-79. doi: 10.1016/j.ecresq.2014.09.001

Scionti, N., Cavallero, M., Zogmaister, C., and Marzocchi, G. M. (2020). Is cognitive training effective for improving executive functions in preschoolers? A systematic review and meta-analysis. Front. Psychol. 10:2812. doi: 10.3389/fpsyg.2019.02812

Solomon, T., Plamondon, A., O'Hara, A., Finch, H., Goco, G., Chaban, P., et al. (2018). A cluster randomized-controlled trial of the impact of the tools of the mind curriculum on self-regulation in Canadian preschoolers. Front. Psychol. 8:2366. doi: $10.3389 /$ fpsyg.2017.02366
Takacs, Z. K., and Kassai, R. (2019). The efficacy of different interventions to foster children's executive function skills: a series of meta-analyses. Psychol. Bull. 145, 653-697. doi: 10.1037/bul0000195

Upshur, C. C., Heyman, M., and Wenz-Gross, M. (2017). Efficacy trial of the second step early learning (SSEL) curriculum: Preliminary outcomes. J. Appl. Dev. Psychol. 50, 15-25. doi: 10.1016/j.appdev.2017.03.004

Webster-Stratton, C. (1994). Advancing videotape parent training: a comparison study. J. Consult. Clin. Psychol. 62, 583-593. doi: 10.1037/0022-006X.62.3. 583

Webster-Stratton, C. (1998). Preventing conduct problems in head start children: strengthening parenting competencies. J. Consult. Clin. Psychol. 66, 715-730. doi: 10.1037/0022-006X.66.5.715

Webster-Stratton, C., Reid, M., and Hammond, M. (2004). Treating children with early-onset conduct problems: intervention outcomes for parent, child, and teacher training. J. Clin. Child Adolesc. Psychol. 33(1):105-124. doi: 10.1207/S15374424JCCP3301_11

Webster-Stratton, C., Reid, M. J., and Hammond, M. (2001). Preventing conduct problems, promoting social competence: a parent and teacher training partnership in head start. J. Clin. Child Psychol. 30, 283-302. doi: 10.1207/S15374424JCCP3003_2

Weiland, C., and Yoshikawa, H. (2013). Impacts of a prekindergarten program on children's mathematics, language, literacy, executive function, and emotional skills. Child Dev. 84, 2112-2130. doi: 10.1111/cdev.12099

Welsh, J. A., Nix, R. L., Blair, C., Bierman, K. L., and Nelson, K. E. (2010). The development of cognitive skills and gains in academic school readiness for children from low-income families. J. Educ. Psychol. 102, 43-53. doi: 10.1037/a0016738

Wolf, R., Morrison, J. M., Inns, A., Slavin, R. E., and Risman, K. (2020). Average effect sizes in developer-commissioned and independent evaluations. J. Res. Educ. Effect. 13, 428-447. doi: 10.1080/19345747.2020.1726537

Conflict of Interest: The authors declare that the research was conducted in the absence of any commercial or financial relationships that could be construed as a potential conflict of interest.

Copyright (-) 2021 Mattera, Rojas, Morris and Bierman. This is an open-access article distributed under the terms of the Creative Commons Attribution License (CC BY). The use, distribution or reproduction in other forums is permitted, provided the original author(s) and the copyright owner(s) are credited and that the original publication in this journal is cited, in accordance with accepted academic practice. No use, distribution or reproduction is permitted which does not comply with these terms. 